\title{
INTEGRATED BIOCHRONOLOGY OF THE PLIOCENE DEPOSITS OF THE ESTEPONA BASIN (MÁLAGA, S SPAIN). PALAEOBIOGEOGRAPHIC AND PALAEOCEANOGRAPHIC IMPLICATIONS
}

\author{
Julio AGUIRRE ${ }^{1^{*}}$, Mario CACHÃO $O^{2}$, Rosa \\ DOMENNECH ${ }^{3}, M^{a}{ }^{a}$ Carmen LOZANO-FRANCIS- \\ $\mathrm{CO}^{4}$, Jordi MARTINELL ${ }^{3}$, Eduardo MAYORAL ${ }^{5}$, \\ Ana SANTOS 6 , José Luis VERA-PELÁEZ ${ }^{4}$ and Car- \\ lo M. DA SILVA ${ }^{2}$
}

\footnotetext{
${ }^{1}$ Dpto. Estratigrafía y Paleontología. Facultad de Ciencias. Fuentenueva s/n. Universidad de Granada. 18071 Granada (Spain). E-mail: jaguirre@ugr.es

${ }^{2}$ Dep. Geologia, Facultad de Ciencias, Univ. Lisboa, Edifício C6, $4^{\circ}$ Piso, sala 55. 1749-016 Lisboa (Portugal). E-mails: mcachao@fc.ul.pt (MC) and Paleo. Carlos@fc.ul.pt (CMS)

${ }^{3}$ Dpto. Estratigrafia, Paleontologia i Geociènces Marines. Facultat de Geologia. Universitat de Barcelona. Martí y Franqués s/n. 08028 Barcelona (Spain).

E-mails: domenech@geo.ub.es (RD) and martinell@geo.ub.es (JM)

${ }^{4}$ Museo Municipal de Estepona (Sección de Paleontología). Matías Prats s/n, Plaza de Toros, 29680 Estepona, Málaga (Spain).

${ }^{5}$ Dpto. Geodinámica y Paleontología. Facultad de Ciencias Experimentales. Unversidad de Huelva. 21071 Huelva (Spain). E-mail: mayoral@uhu.es

${ }^{6}$ Centro de Investigação Marinha e Ambiental, Faculdade de Ciências do Mar e do Ambiente, Universidade do Algarve, Campus de Gambelas.8000-117 Faro (Portugal). E-mail: aasantos@ualg.pt
}

* Corresponding author

Aguirre, J., Cachão, M., Domènech, R., Lozano-Francisco, Mª C., Martinell, J., Mayoral, E., Santos, A., VeraPeláez, J. L. \& Da Silva, C. M. 2005. Integrated biochronology of the pliocene deposits of the Estepona basin (Málaga, S Spain). Palaeobiogeographic and palaeoceanographic implications. [Biocronología integrada de los depósitos pliocenos de la cuenca de Estepona (Málaga, S de España). Implicaciones paleobiogeográficas y paleoceanográficas.] Revista Española de Paleontología, 20 (2), 225-244. ISSN 0213-6937.

\begin{abstract}
In the Estepona basin (Málaga, S Spain), the richest and the most diverse Pliocene sites of marine invertebrates (mostly molluscs) of the Mediterranean are found. Most of the species described up until now ( $95 \%$ out of 892 identified species) occur at the Parque Antena and the Velerín Area (Velerín, Velerín-Carretera and Velerín-Antena) sites. Although molluscs are very well known, the age of these important sites is still controversial. In this paper, a biochronological study of these sites based on an integrated study of the microfossil (calcareous nannoplankton and planktonic foraminifers) and macrofossil (molluscs) assemblages is presented.

The Parque Antena and Velerín-Carretera sites can be attributed to the late Zanclean (uppermost part of the early Pliocene) based on the presence of Globorotalia margaritae, Gr. puncticulata and Gr. group crassaformis (including Gr. crassaformis s.s.). Nannoplankton assemblages agree with this age, and can be attributed to the CN11b biozone of Okada \& Bukry (1980) due to the presence of small Gephyrocapsa, Sphenolithus abies and Reticulofenestra pseudoumbilica. At the Velerín-Antena section, the bioindicators of the early Pliocene Gr. margaritae, Sphenolithus abies and Reticulofenestra pseudoumbilica are absent. The microfossil assemblages are characterised by the occurrence of Gr. puncticulata and Gr. group crassaformis among foraminifers and Discoaster asymmetricus and D. tamalis among nannoplankton. This microfossil assemblage allows us to attribute this site to the lowermost Piacenzian (middle Pliocene): biozone CN12a of Okada \& Bukry (1980).

The molluscs found in the studied sites correlate with the Mediterranean Pliocene Molluscan Unit 1 of Raffi \& Monegatti (1993) (MPMU1). This unit ranges from the base of the Zanclean (base of the early Pliocene) to
\end{abstract}


the lower half of the Piacenzian (middle Pliocene; $3 \mathrm{Ma}$ ). This age attribution is consistent with that inferred from microfossils.

Finally, the coexistence of Gr. margaritae and Gr. group crassaformis in the Mediterranean domain is described for the first time, so far. These two species coexisted during ca. $600 \mathrm{ka}$ in the Atlantic Ocean, thus the coincidence of both species in the western Mediterranean can be related to the occasional invasion of inhabitants from the Atlantic by superficial currents through the Strait of Gibraltar.

Key words: Pliocene, planktonic foraminifers, calcareous nannoplankton, molluscs, Estepona (S Spain), biochronostratigraphy, palaeoceanography.

\section{RESUMEN}

En la cuenca de Estepona (Málaga, S de España) se encuentran los yacimientos pliocenos con mayor diversidad y más ricos en invertebrados marinos (mayoritariamente moluscos) del Mediterráneo. La mayoría de las especies descritas hasta el momento ( $95 \%$ de 892 especies identificadas) se encuentran en los yacimientos de Parque Antena y Área de Velerín (yacimientos de Velerín, Velerín-Carretera y Velerín-Antena). Aunque los moluscos de estos yacimientos están muy bien estudiados, la edad de los yacimientos aun es tema de controvertido debate. En este trabajo, se presenta un estudio biocronológico integrado de estos yacimientos mediante el análisis de las asociaciones de microfósiles (nanoplancton calcáreo y foraminíferos planctónicos) y de macrofósiles (moluscos).

Los yacimientos de Parque Antena y Velerín-Carretera pueden atribuirse al Zancliense superior (parte alta del Plioceno inferior) por la presencia de Globorotalia margaritae, Gr. puncticulata y Gr. grupo crassaformis (incluyendo Gr. crassaformis s.s). Las asociaciones de nanoplancton calcáreo confirman esta edad y pueden atribuirse a la biozona CN11b de Okada \& Bukry (1980) por la presencia de pequeñas Gephyrocapsa, Sphenolithus abies y Reticulofenestra pseudoumbilica. En Velerín-Antena, los indicadores bioestratigráficos del Plioceno inferior, Gr. margaritae, Sphenolithus abies y Reticulofenestra pseudoumbilica no se encuentran. Las asociaciones de microfósiles están caracterizadas por la presencia de Gr. puncticulata y Gr. grupo crassaformis entre los foraminíferos planctónicos, y Discoaster asymmetricus y D. tamalis entre el nanoplancton calcáreo. Esta asociación de microorganismos permite atribuir este yacimiento a la parte basal del Piacenziense (Plioceno medio): biozona CN12a de Okada \& Bukry (1980).

Los moluscos encontrados en estos yacimientos se incluyen en la Unidad 1 de Moluscos Pliocenos del Mediterráneo de Raffi \& Monegatti (1993) (MPMU1). Esta unidad se extiende desde la base del Zancliense (base del Plioceno inferior) a la parte media del Piacenziense (Plioceno medio; $3 \mathrm{Ma}$ ). Esta atribución cronológica es consistente con la inferida a partir de los microfósiles.

Finalmente, se describe por primera vez la coexistencia de Gr. margaritae y Gr. grupo crassaformis en el Mediterráneo. Estas dos especies coexistieron durante aproximadamente $600 \mathrm{ka}$ in el Océano Atlántico, así que la coincidencia de ambas especies en el Mediterráneo occidental puede relacionarse con la invasión ocasional de inmigrantes desde el Atlántico siguiendo corrientes superficiales a través del Estrecho de Gibraltar.

Palabras claves: Plioceno, foraminíferos planctónicos, nanoplancton calcáreo, moluscos, Estepona (S de España), biocronoestratigrafía, paleoceanografía.

\section{INTRODUCTION}

An intense taxonomic research of the macrofossil assemblages, mainly molluscs (bivalves, gastropods and scaphopods), of the Estepona basin (Málaga, S Spain) has revealed that the Pliocene sediments contain the richest fossil assemblages of the Mediterranean domain (LozanoFrancisco et al., 1993; Vera-Peláez et al., 1993, 1995a, 1995b, 1999; Muñiz-Solís et al., 1996; Vera-Peláez Aguilà, 1996; Lozano-Francisco, 1997, 1998; Vera-Peláez \& Lozano-Francisco, 1998a, 1998b; 2002; Vera-Peláez, 2002; Muñiz-Solís, 2002; Lozano-Francisco \& Vera-Peláez, 2002). The relevance of these taxonomic investigations is twofold. On the one hand, nearly 1,300 species of ma- rine invertebrates have been identified, 892 of which are molluscs. Out of these 892 species, 674 are gastropods, 198 correspond to bivalves, and 20 are scaphopods. On the other hand, 68 species of gastropods are endemism of the Estepona basin: 35 species belong to the family Turrideae; 16 to Marginellidae; 13 to Archeogastropoda; 3 to Cysticidae; and 1 to Cancellariidae. The exceptional preservation of the fossils has allowed to carrying out this exhaustive taxonomic research. Gastropods often preserve the initial whorls of early ontogenetic stages, crucial for species identification. Furthermore, shells of molluscs often preserve their original colour patterns.

The Parque Antena section and the Velerín Area (Velerín, Velerín-Carretera and Velerín-Antena sites) are the 
most diversified and the richest palaeontological sites of the Estepona basin (Fig. 1), where almost all the described mollusc species have been found.

Despite the great taxonomical knowledge of the molluscs of the Estepona basin, the age of the deposits in which they occur is still controversial. Ansted (1857) assigned these deposits to the "Older Pliocene" period following the stratigraphic division of the Pliocene established by Lyell (1833). After this chronological attribution, since the end of the XIX century, authors have traditionally assigned the Pliocene deposits of Marbella and Estepona to the middlelate Pliocene (Lévy \& Bergeron, 1892; Bertrand \& Kilian, 1892; González-Donoso \& de Porta, 1977; Chamon et al., 1978). Specifically, Guerra-Merchán et al. (2002) attributed the Parque Antena and Velerín Area sites to the biozone MPl 4b of Cita (1975) or Globorotalia aemiliana biozone of Iaccarino (1985); that is, Piacenzian (middle Pliocene). This age attribution is based on the occurrence of Globorotalia crassaformis Galloway \& Wissler 1927, Gr. aemiliana Colalongo \& Sartoni 1967, Gr. bononiensis Dondi 1963, Globigerinoides ruber (d'Orbigny) Banner \& Blow 1960, Gd. elongatus (d'Orbigny) Banner \& Blow 1960 and $G d$. extremus Bolli \& Bermúdez 1965. However, Aguirre (1995a) included these sediments in the early Pliocene based on regional stratigraphic correlation along the southern margin of Spain, and on biostratigraphic results from samples recovered in different localities along the coast of Málaga.

An integrated study of the microfossil assemblages (planktonic foraminifers and calcareous nannoplankton) has been carried out in the Parque Antena and Velerín (Velerín, Velerín-Carretera and Velerín-Antena) sites to establish their temporal framework. This microfossil analysis is crucial to better understand further-reaching topics, such as the macroevolutionary patterns of the fauna during the Pliocene. In this respect, Raffi et al. (1985, 1989), Raffi \& Monegatti (1993) and Monegatti \& Raffi (2001) detected several extinction events of molluscs in the Mediterranean during the middlelate Pliocene. These extinction events were probably related to the stepwise global climatic cooling caused by the onset of the Northern Hemisphere glaciation, starting at $\sim 3 \mathrm{Ma}$ (Piacenzian, middle Pliocene) and culminating at $\sim 2.4 \mathrm{Ma}$

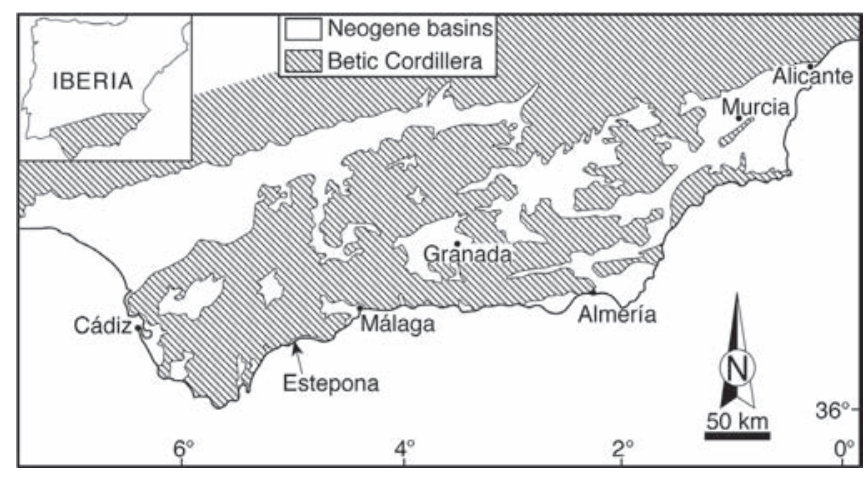

Figure 1. Map of the Neogene basins of the Betic Cordillera.
(Gelasian, late Pliocene) (Shackleton et al., 1984; Keigwin, 1986; Ruddiman \& Raymo, 1988; Dowsett \& Poore, 1990; Maslin et al., 1998; Thiede et al., 1998).

Another important aspect that could be affected by the timing of the Estepona fauna is the palaeobiogeographic relationships of the fossil assemblages between the Mediterranean and the adjacent Atlantic Ocean (patterns of fauna displacements, interchanges of species, immigrants, emigrants, etc). In relation to this, the coexistence of Globorotalia margaritae Bolli \& Bermúdez 1965 and Gr. crassaformis is reported for the first time in this paper. Since these two species of planktonic foraminifers have never been found together in the Mediterranean, this finding is crucial in inferring faunal interchanges between the Atlantic and the Mediterranean through the Strait of Gibraltar, probably related to palaeoceanographic circulation models. This aspect is also discussed in this paper.

\section{GEOGRAPHICAL LOCATION AND GEOLOGICAL CONTEXT}

The Velerín Area sites (Velerín, Velerín-Carretera and Velerín-Antena) are exposed along the Velerín valley, about $4 \mathrm{~km}$ ENE of Estepona, while the Parque Antena site crops out in a section ca. $8 \mathrm{~km}$ ENE of Estepona (Fig. 2). According to the palaeogeographic reconstruction (Fig. 3), the studied sites were located at the northwestern margin of the Alborán Sea.

The Pliocene deposits of the Málaga region are exposed along the coast and extend landward through the presentday river valleys (Figs. 1-2). They unconformably overlay different lithological units of the Inner Zone of the Betic

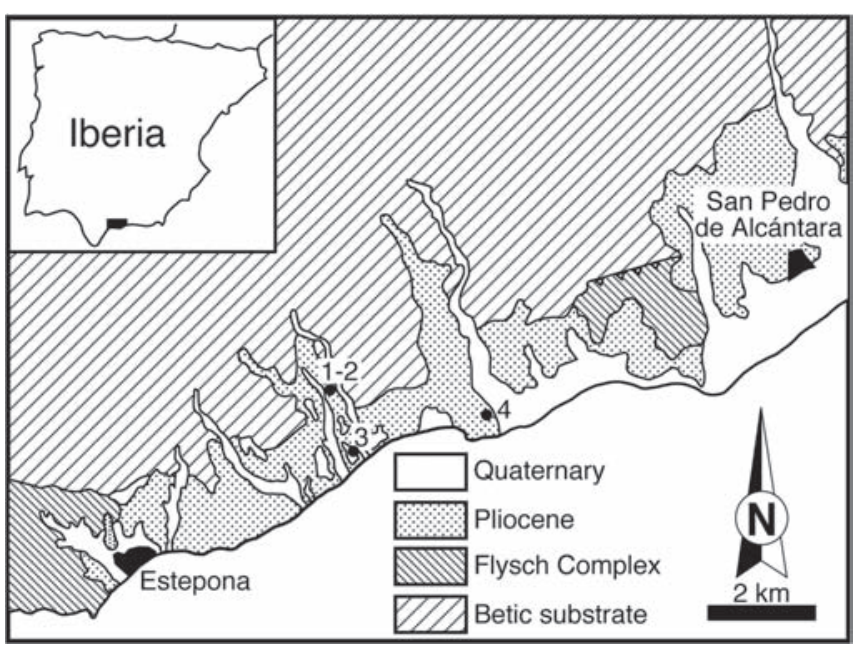

Figure 2. Geological map of the studied area indicating the location of the studied sections. 1: Velerín; 2: VelerínAntena; 3: Velerín-Carretera; 4: Parque Antena (modified from Vera-Peláez et al., 1995b). 
Cordillera and the sandstones of the Campo de Gibraltar Flysch Complex. The Pliocene sediments exposed in this region are lithologically homogeneous and show similar facies. They consist of blue marls (locally known as "Margas de Tejares"), silts, sands and conglomerates. Locally, in the Nerja, Almayate and Estación Valle-Niza basins (Fig. 3), the Pliocene deposits are made up of calcarenites and calcirudites with variable amounts of siliciclastic components (Guerra-Merchán \& Serrano, 1993; Mayoral \& Rodríguez-Vidal, 1994; Aguirre, 1995a, 2000). These calcareous sediments were formed in areas starved or with low influence of siliciclastic inputs.

In the Estepona basin, the Pliocene sediments are deposited on metamorphic rocks of the Sierra Bermeja and on sandstones of the Campo de Gibraltar Flysch Complex, which crop extensively out W of Estepona and W of San Pedro de Alcántara (Fig. 2). The Pliocene deposits in the Estepona basin form a single unit (Aguirre, 1995a), starting with channelled breccias and conglomerates on top of the Betic basement of the Sierra Bermeja at the northern margin of the basin. Coarse-grained sands are intercalated among the conglomerates and breccias. Fossil invertebrates are very abundant both in the conglomerates and in the sands. Upward into the unit, as well as laterally to the south, the sediments change to very fossiliferous medium- to fine-grained sands and silts. These facies are locally known in the region as "bizcornil". Locally, blue marls crop out in the southernmost areas.

The Pliocene sediments were formed in a fan delta, and the observed N-S facies change is interpreted as a proximal to distal change in the depositional settings. Thus, the conglomerates and breccias with the coarse-grained sands in the northern part of the basin correspond to the inner fan-delta facies, while the medium- to fine-grained sands of the southern areas represent the outer fan-delta deposits. The silts can be attributed to the distalmost (southernmost areas) deposits of the outer fan-delta in the transition to the basin, where the blue marls were deposited.

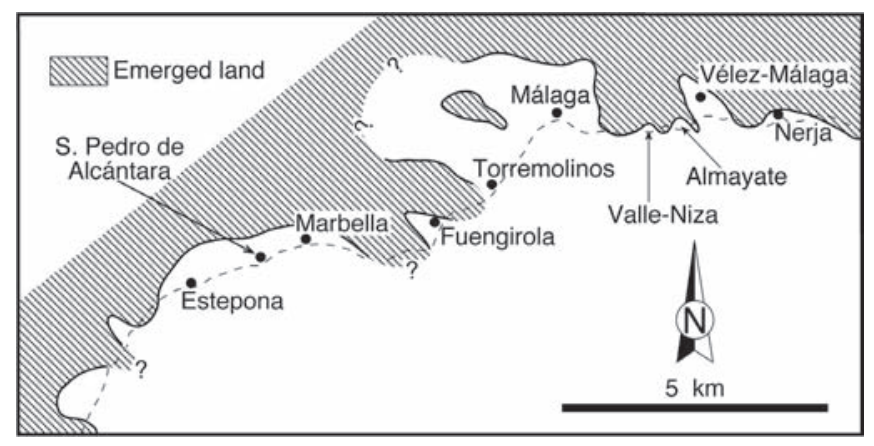

Figure 3. Palaeogeographic map of the province of Málaga (S Spain) during the Pliocene (modified from Aguirre 1995a)

\section{STRATIGRAPHY OF THE STUDIED SECTIONS}

\section{VELERÍN SECTION}

Velerín is the northernmost studied section in the Velerín area (site 1 in Fig. 2). The Pliocene deposits at this site are up to 6 $\mathrm{m}$ thick. These deposits are sub-horizontal, with a very gentle dipping $\left(\sim 5^{\circ}\right)$ to the south. They consist of conglomerates with intercalations of up to 30 -cm-thick coarse-grained sand beds (Figs. 4 and 5a-b). Conglomerates are composed of centimetre to decimetre clasts of metamorphic rocks coming from the Sierra Bermeja substrate. Major components are gneis, schist, quartzite, marble and peridotite clasts mostly spherical and rounded in shape. Occasionally, amalgamation of several channelled beds is observable. These channelled beds often show a normal grading and large-scale trough-cross stratiphication.

Coarse-grained sands occur as lens-shaped bodies within the conglomerates. They are massive and contain some metamorphic grains and granules (up to $2-3 \mathrm{~cm}$ across) dispersed in the matrix.

Fossil invertebrates, mostly molluscs, are abundant in this site, both in the conglomerates and in the sands. In the vicinity to this site, Vera-Peláez (1996) and Lozano-Francisco (1997) described about $90 \%$ of the total mollusc species found in the whole Estepona Basin in the locality called Velerín-Pared. Fossils are exceptionally well preserved, maintaining their original aragonitic shells. In cases, gastropods also preserve the protococh and traces of the original colour pattern.

Predominance of conglomerates, amalgamation of channelled conglomeratic beds, size of the boulders and cobbles, and the fossil content indicate that these deposits represent the inner fan-delta facies. Clast morphology and sedimentary structures suggest a considerable transport from the source area and an important reworking by hydraulic currents within the depositional setting.

\section{VELERÍN-ANTENA SECTION}

This section is ca. $500 \mathrm{~m} \mathrm{~S}$ of the previous one (site 2 in Fig. 2). The lower part of this section can be laterally correlated with the uppermost part of the Velerín section, thus constituting the upward continuation of the Pliocene unit. This stratigraphic relationship is easily observable in the field.

The Pliocene deposits at Velerín-Antena section (Fig. 4), up to $20 \mathrm{~m}$ thick, are monotonously represented by fossiliferous medium- to fine-grained sands ("bizcornil" facies) (Fig. 5c). These sands are massive and very homogeneous. Conglomeratic beds, up to $30 \mathrm{~cm}$ in thickness, are occasionally intercalated in the lower part of the section. These conglomerates are made up of metamorphic rocks, up to 5-7 cm in diameter, of the Sierra Bermeja basement. These beds show channelled bases and normal grading.

Fossils are dispersed in the sands, although occasionally they concentrate in thin beds, less than $5 \mathrm{~cm}$ thick. Together with fossil invertebrates, fragments of plant remains are present.

The lower part of the Velerín-Antena section is interpreted as the transition from the inner to the outer fan-delta facies. Higher up into the sequence, the dominance of homogeneous and massive medium- to fine-grained sands represent the establishment of the outer fan-delta facies. Presence of plant remains confirms the interpretation of a fan-delta depositional system. 


\section{VELERÍN-CARRETERA SECTION}

This section, up to $4 \mathrm{~m}$ thick, is located less than $2 \mathrm{~km} \mathrm{~S}$ of the previous ones (site 3 in Fig. 2). The Velerín-Carretera section is very monotonous since the Pliocene deposits consist of "bizcornil"type facies (Figs. 4 and 5d-e); that is, medium- to fine-grained fossiliferous sands. They contain a very rich fossil content.

The lower part of the section consists of silts and fine-grained sands. Up into the section, sediments increase the grain size, changing to fine- and medium-grained sands. Plant remains are also associated with fossil invertebrates.

The correlation of this section with the previous Velerín and Velerín-Antena sections is not observed in the field.

The silts and fine-grained sands of the lower part of the section correspond with the transition from the outer fan-delta to the platform settings. The observed upward change in grain size is interpreted as the transition to the outer fan-delta deposits as this system prograded to the $\mathrm{S}$. Presence of plant remains is consistent with this interpretation.

\section{PARQUE ANTENA SECTION}

The Parque Antena section (Fig. 4), up to $7 \mathrm{~m}$ in thickness, dips to the $\mathrm{S}$ (Fig. 5f). It consists of fine-grained sands and silts with beds of coarser-grained sands with trough cross-lamination at the base of the section (Fig. 4). Small channelled bodies of conglomerates are intercalated in the first $60 \mathrm{~cm}$ of the section. Clasts, up to $2 \mathrm{~cm}$ across, are metamorphic rocks coming from the Sierra Bermeja substrate. A thick channel (1.3 $\mathrm{m}$ in thickness) of medium- to fine-grained sands with small-scale through-cross stratiphication is in the lower part of the section (Fig. 4). Abundant fossil invertebrates and small pieces of carbonaceous plant remains are dispersed in these deposits. Sediment changes to homogeneous and massive silts up into the section (Fig. 4).

These deposits are interpreted to be formed in distal fandelta and basinal settings. No lateral relationship between the Parque Antena section with the Pliocene deposits of the previous sections in the Velerín area is observed in the field. The Parque Antena section is considered the laterally related deposits to those of the Velerín-Carretera section (see biostratigraphic correlation below).

\section{METHODOLOGY}

Several samples were collected in the different sections (Fig. 4): six samples in Parque Antena, five in Velerín-Carretera, five in Velerín-Antena, and one in Velerín. For the study of the

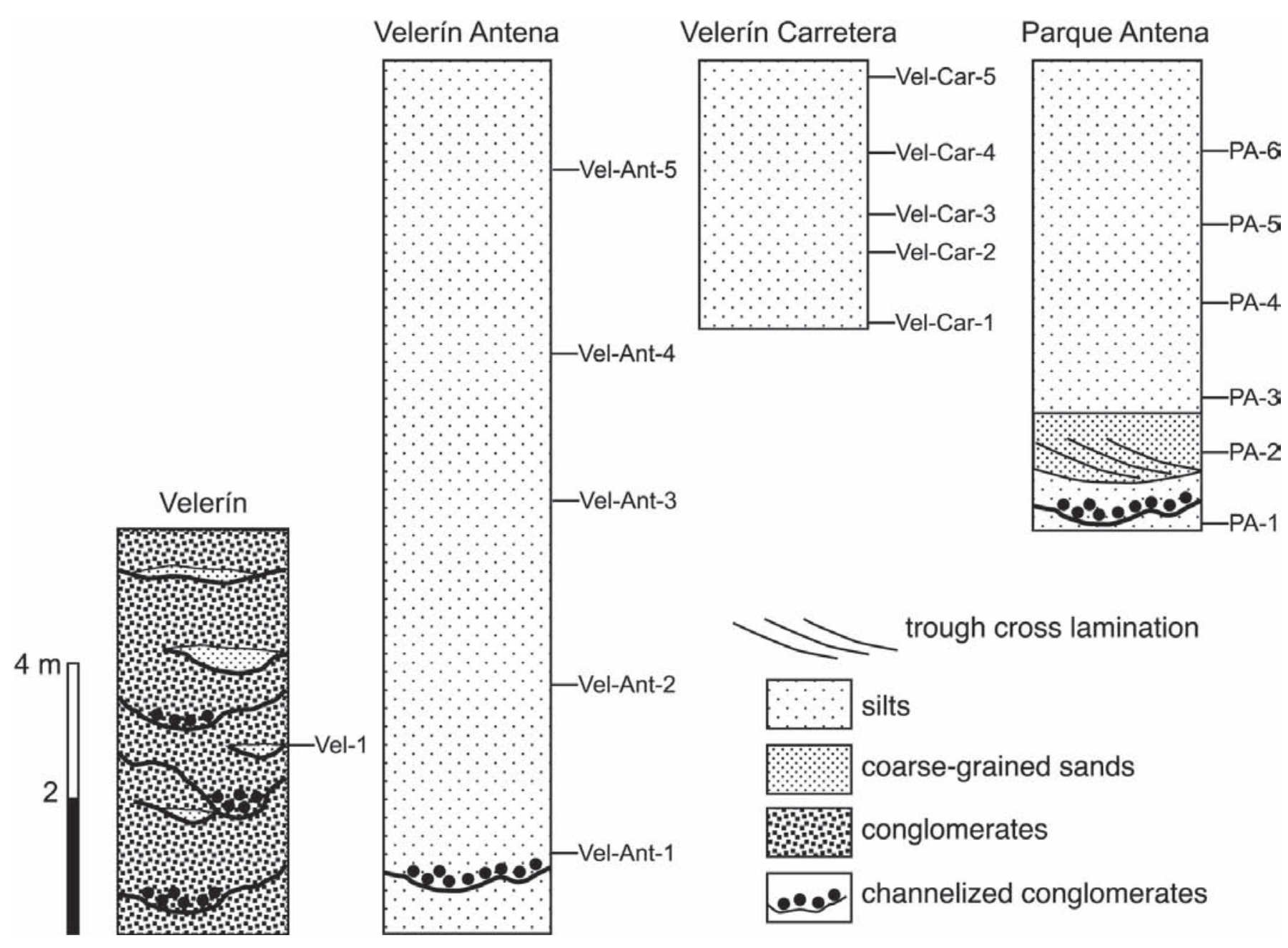

Figure 4. Stratigraphic columns of the studied sections indicating the position of the collected samples. 

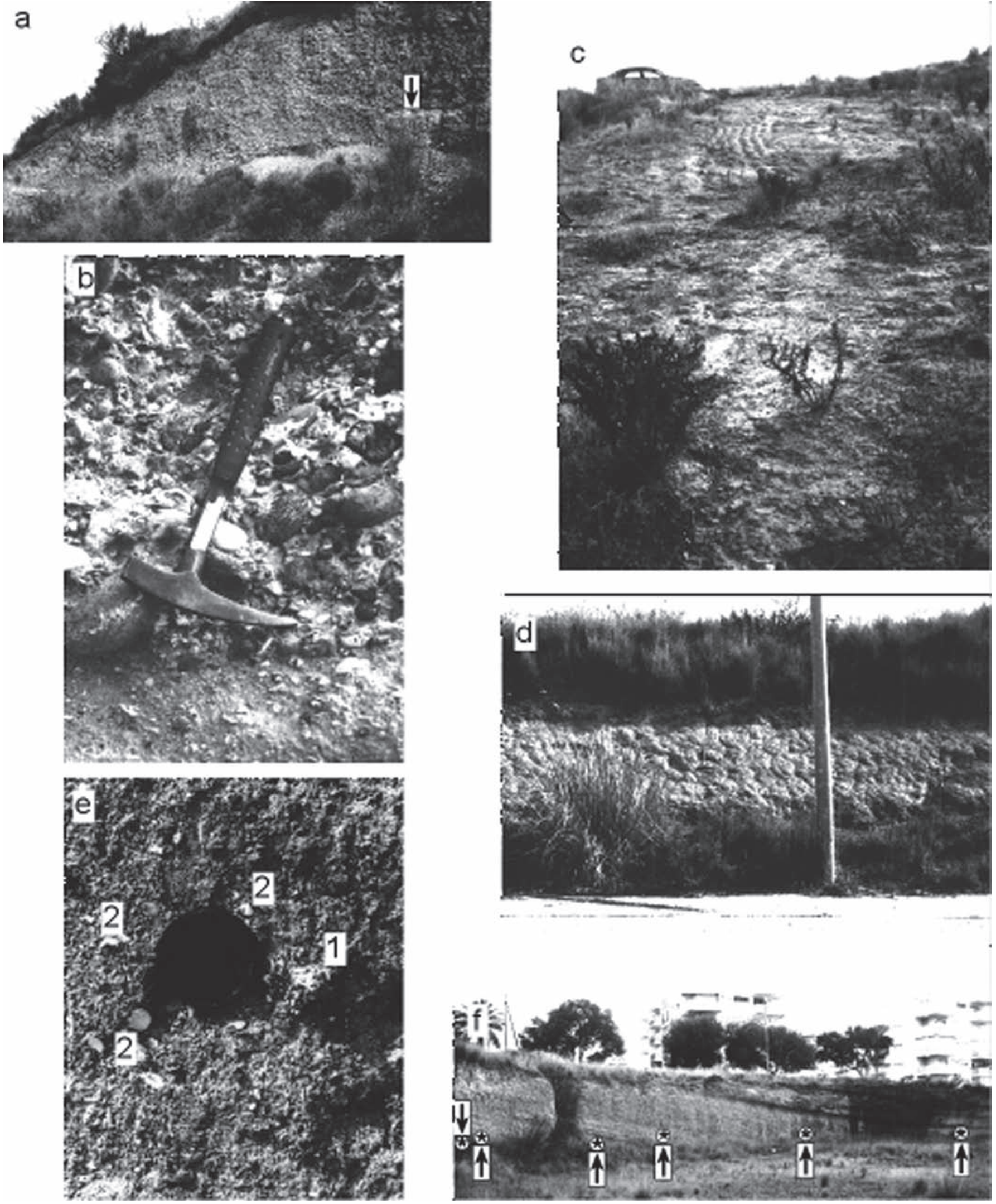

Figure 5. Field view of the studied sites. a, channelized conglomerates and coarse-grained sand beds intercalated in the Velerín site; arrow indicates the location of the sample. b, a detailed view of the bioclastic coarse-grained sand bed where the studied sample was collected. c, location of the sample at the Velerín-Antena site. d, field view of the Velerín-Carretera site. e, a close-up view of the, fossiliferous silt and fine-grained sands of the previous outcrop. 1: vermetid; 2: bivalves. f, the Parque Antena site indicating the location of the six studied samples (arrows pointing asterisks). 
planktonic foraminifers about $1 \mathrm{~kg}$ of sediment was sieved. The residue from the fraction $125 \mu \mathrm{m}$ was analysed.

Due to the presence of significant coarse-grained sediment in some of the samples, they were pre-prepared for calcareous nannofossils through prompt stir and settling into a test tube for separation of the silty-clay fraction. A portion of this fraction was flooded into a coverslip with a pipette and smeared with a flat-sided toothpick all over its surface, allowing for the development of ripples of variable concentration by gentle friction. The preparation is then rapidly dried on a hotplate and permanently affixed using an optical mounting medium (Entellan $®)$. The preparation is scanned for biostratigraphic markers on a petrographic microscope with $1250 x$ magnification.

\section{RESULTS}

\section{PLANKTONIC FORAMINIFER ASSEMBLAGES}

In general, all the studied samples show a very high content of foraminifers, both planktonic and benthonic. The foraminifer assemblages of the Parque Antena samples show a high proportion of the planktonic/benthonic ratio. This is consistent with the inferred environmental conditions in which these sediments were formed (in the transition from the outer fan-delta to the basin).

Assemblages of planktonic foraminifers in the Parque Antena section are clearly dominated by Globorotalia puncticulata (Deshayes 1832) Banner \& Blow 1970 (Fig. 6a) and Globigerinoides spp. Among the latter, Globigerinoides trilobus (Reuss) Tjalsma 1971 and Gd. sacculifer Brady 1884 are especially abundant in the PA-4 sample, dominating the assemblage. Other abundant species often found in the samples are Orbulina universa d'Orbigny 1839, Globigerina decoraperta Takayanagi \& Saito 1962, Globigerinita sp. and Globorotalia scitula (Brady) Banner \& Blow 1960. These species are irregularly distributed through the section.

Among the dominant species, other biostratigraphically significant ones are present. In the PA-2 sample, associated with the aforementioned species, Globorotalia group crassaformis (see Taxonomic Appendix) and Sphaeroidinellopsis seminulina (Schwager) are found (Figs. 6b-d). Additionally, in the PA-5 and PA-6 samples, the occurrence of Globorotalia margaritae is confirmed (Figs. 6e-f). Together with this species, Gr. puncticulata and Gr. group crassaformis are also found.

In the three localities of the Velerín Area, foraminifers are also very abundant, except at the Velerín section, where only a few specimens of benthonic foraminifers occur. The sample in this section was collected in a coarse-grained sand bed intercalated in the channelled conglomerates (Fig. 5b). As mentioned above, these sediments were deposited in a proximal inner fan-delta setting. Therefore, the shallow environmental conditions account for the scarcity of foraminifers (and the virtual absence of planktonic forms) in this sample.
Both planktonic and benthonic foraminifers, as well as ostracod carapaces, are very abundant in the VelerínCarretera section, except the first sample (Vel-Car-1), in which a few benthonic foraminifers are only present. The samples are dominated by Globigerinoides spp (mainly Gd. extremus Bolli 1957, Gd. obliquus Bolli 1957 and $G d$. ruber d'Orbigny 1839), Globigerina spp. and Gr. puncticulata. Gr. crassaformis s.s. is present throughout the section, although it is relatively abundant in sample Vel-Car3 (Figs. 7a-c). Associated planktonic foraminifers are $O$. universa, Neogloboquadrina acostaensis Blow 1959, N. humerosa Takayanagi \& Saito 1962, Globigerinella sp. and Sphaeroidinellopsis sp. Occasional individuals of $G r$. scitula are present (Vel-Car-2). Gr. margaritae is found in the uppermost Vel-Car-5 sample (Figs. 7c-f).

From a biostratigraphic point of view, it is worth mentioning the presence of Gr. margaritae, Gr. crassaformis s.s. and Gr. puncticulata. All these three species can coexist together in a sample (Vel-Car-5).

Finally, foraminifer assemblages at the Velerín-Antena section are dominated by benthonic forms (low planktonic/benthonic ratio), mainly Ammonia and Elphidium. Ostracods are also very abundant in this section. The low planktonic/benthonic ratio and the dominance of these two benthonic forms suggest, and are consistent with, a shallow proximal depositional setting. The planktonic foraminifer assemblages are dominated by Globigerinoides spp. (mostly $G d$. extremuns and $G d$. ruber) and $G r$. puncticulata. Accompanying planktonic foraminifers are $O$. universa, Globigerinella sp., Globigerina spp. and scarce Neogloboquadrina spp. Gr. crassaformis s.s. occurs in the sample Vel-Ant-4 together with Sphaeroidinellopsis and Gr. puncticulata (Fig. 8).

\section{CALCAREOUS NANNOPLANKTON ASSEMBLAGES}

Both the Parque Antena and Velerín Area sites show exceptionally abundant and rich nannofossil assemblages (coccoliths and other nannoliths) (Fig. 9 and Table 1). The preservation of the nannofossils is also exceptional since complete coccospheres are often found. However, there are also reworked specimens from older deposits: Cretaceous, Palaeogene and Miocene. High proportion of reworked specimens, together with the presence of the shallow species Braarudosphaera bigelowi (Gran \& Braarud 1935) Deflandre 1947, indicates shallow palaeoenvironmental conditions. This is confirmed by the low abundance of open oceanic water nannoplankton forms, such as Discoaster spp., Sphenolithus spp. and Ceratolithus spp.

The samples from the Parque Antena section are clearly dominated by small Gephyrocapsa (less than $3 \mu \mathrm{m}$ ) together with reticulofenestrids (Reticulofenestra haqii Backman 1978, R. minutula (Gartner) Haq \& Berggren 1978, R. minuta Roth 1970), Helicosphaera carteri (Wallich) Kamptner 1954 and Coccolithus pelagicus (Wallich) Schiller 1930 (Table $1)$. The presence of nannoplankton species typically inhab- 
iting open oceanic conditions, such as Ceratolithus cristatus Kamptner, 1950, Scyphosphaera spp., Syracosphaera spp. and Umbilicosphaera sibogae (Weber-Van Bosse) Gaarder, 1970, together with richer and more diverse Discoaster assemblages, in the last two samples of the Parque Antena section (Table 1) confirms the upward deepening previously inferred based on planktonic foraminifers.

From a biostratigraphic point of view, the species $R e$ - ticulofenestra pseudoumbilica (larger than $7 \mu \mathrm{m}$ ) and Sphenolithus abies are found throughout the Parque Antena section. Additionally, the discoasterids Discoaster asymmetricus, D. tamalis, D. brouweri (Tan Sin Hok) Bramlette \& Riedel 1954, D. surculus Martini \& Bramlette 1963 and D. variabilis Martini \& Bramlette 1963 are the dominant nannoliths, and are present in almost all the samples (Table 1).

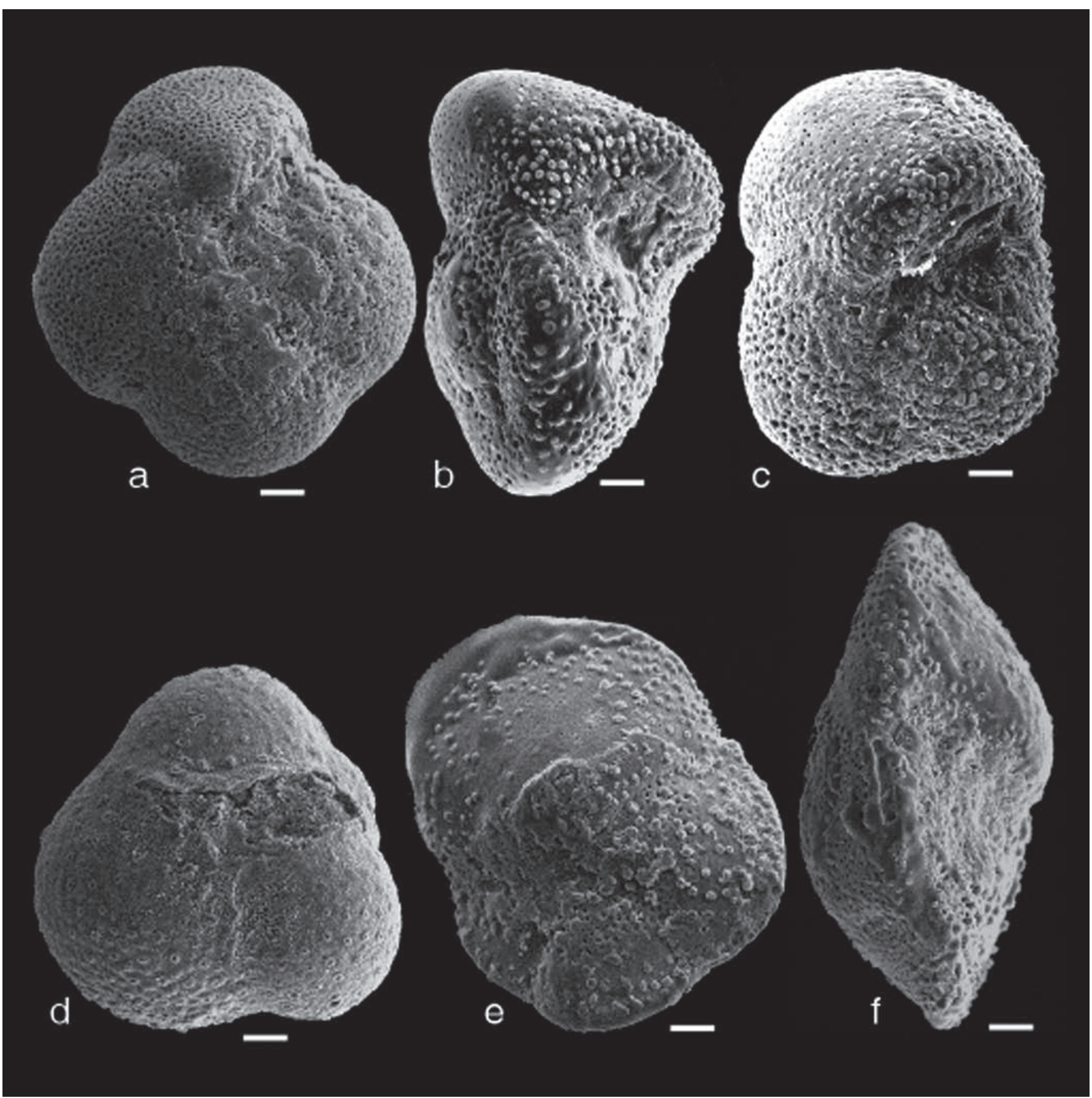

Figure 6. Planktonic foraminifers of biostratigraphic significance found in Parque Antena section. a, Globorotalia puncticulata (Deshayes 1832) Banner \& Blow 1970, umbilical view (sample PA-5). b-c, Globorotalia crassaformis group, lateral (b) and umbilical (c) views (sample PA-5). d, Sphaeroidinellopsis seminulina (sample PA-2). e-f, Globorotalia margaritae Bolli \& Bermúdez 1965, umbilical (e) and lateral (f) views (sample PA-6). 


\begin{tabular}{|c|c|c|c|c|c|c|c|c|c|c|c|c|c|c|c|c|c|c|c|c|c|c|c|c|c|c|c|c|c|c|c|c|c|c|c|c|c|}
\hline $\begin{array}{l}\frac{\mathrm{g}}{\mathrm{e}} \\
\frac{\mathrm{E}}{\mathrm{g}}\end{array}$ & 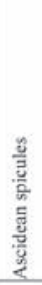 & 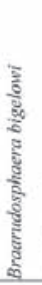 & 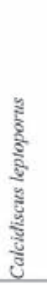 & 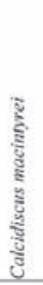 & $\begin{array}{l}\text { जू } \\
\text { है } \\
\text { है } \\
\text { है } \\
\text { हूँ }\end{array}$ & 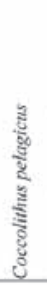 & 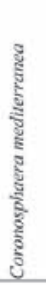 & 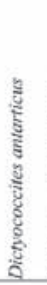 & 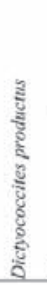 & 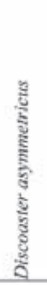 & 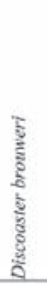 & 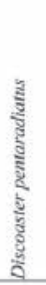 & 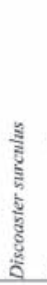 & 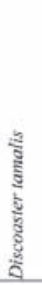 & 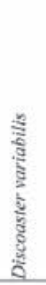 & 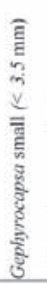 & 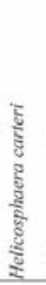 & 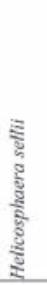 & 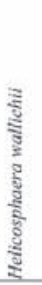 & 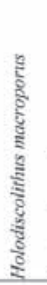 & 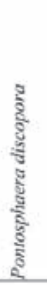 & 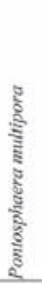 & 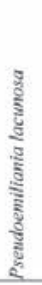 & 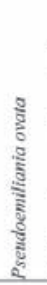 & 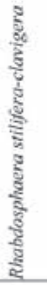 & 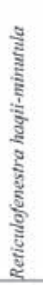 & 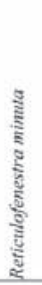 & 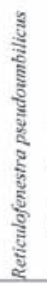 & 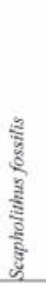 & 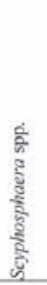 & 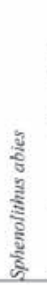 & 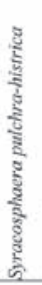 & 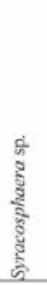 & 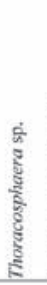 & $\begin{array}{l}\frac{5}{5} \\
\frac{5}{5} \\
\frac{5}{5} \\
\frac{5}{5} \\
\frac{5}{5} \\
\text { है }\end{array}$ & 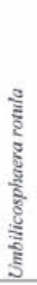 & 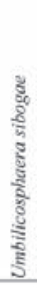 \\
\hline Parque Antena 1 & & & 2 & 1 & & 3 & & 1 & & & & & & & & 4 & 2 & 1 & & 1 & 1 & & & & & 3 & 3 & & & & 1 & 1 & & & 1 & & \\
\hline Parque Antena 2 & & & 2 & 1 & & 2 & & 1 & & & & & & & & 4 & 2 & 1 & 1 & & 1 & 1 & & 1 & 1 & 2 & 3 & 1 & & & 2 & 1 & 1 & & 1 & 1 & \\
\hline Parque Antena 3 & & & 2 & & & 1 & & 1 & 1 & & & & & & & 4 & 3 & 1 & 1 & 1 & 1 & & & 1 & 1 & 3 & 3 & & & & 1 & 1 & 1 & 1 & 1 & 1 & \\
\hline Parque Antena 4 & 1 & & 2 & 1 & & 2 & & 1 & & & & & & & & 4 & 3 & 2 & & & 2 & & & & & 3 & 3 & & & 1 & 1 & 1 & 2 & & 2 & 1 & \\
\hline Parque Antena 5 & & 1 & 2 & 1 & & 3 & & 1 & & & 1 & & & & 1 & 4 & 2 & 2 & & & 2 & & 1 & 2 & 1 & 3 & 3 & 1 & & 1 & 1 & 1 & 2 & 1 & 2 & 2 & 1 \\
\hline Parque Antena 6 & & & 2 & 1 & 1 & 3 & & & & & 2 & & & 1 & 1 & 4 & 3 & 3 & 1 & & 2 & & & 2 & 1 & 4 & 3 & 2 & & 1 & 2 & 1 & 2 & & 2 & 3 & 1 \\
\hline Velerin & & & & & & & & & 1 & & & & & & & 1 & 1 & & & & & & & & & 1 & 1 & & & & & & & & & & \\
\hline Velerin Carretera & 1 & 1 & 3 & 1 & & 3 & 1 & 1 & & 1 & 1 & 1 & 1 & 1 & 1 & 4 & 2 & 2 & 1 & 1 & 2 & 1 & 1 & 1 & 1 & 3 & 3 & 1 & 1 & 2 & 1 & 1 & 1 & & & 1 & \\
\hline Velerin Antena & & & 3 & 1 & & 3 & 1 & & 1 & 1 & 1 & & & & & 3 & 2 & 1 & & & 1 & & 1 & & & 3 & 2 & & & 1 & & 1 & 1 & & & 1 & \\
\hline
\end{tabular}

Table 1. Distribution and abundance of nannoplankton species in the studied samples. Key: 1.- Rare (one coccolith in more than 10 fields of observation); 2.- Common (one cocolith in less than 10 fields of observation); 3.- Frequent (1-10 cocolith per fields of observation); 4.- Abundant (more than 10 cocolith per fields of observation).

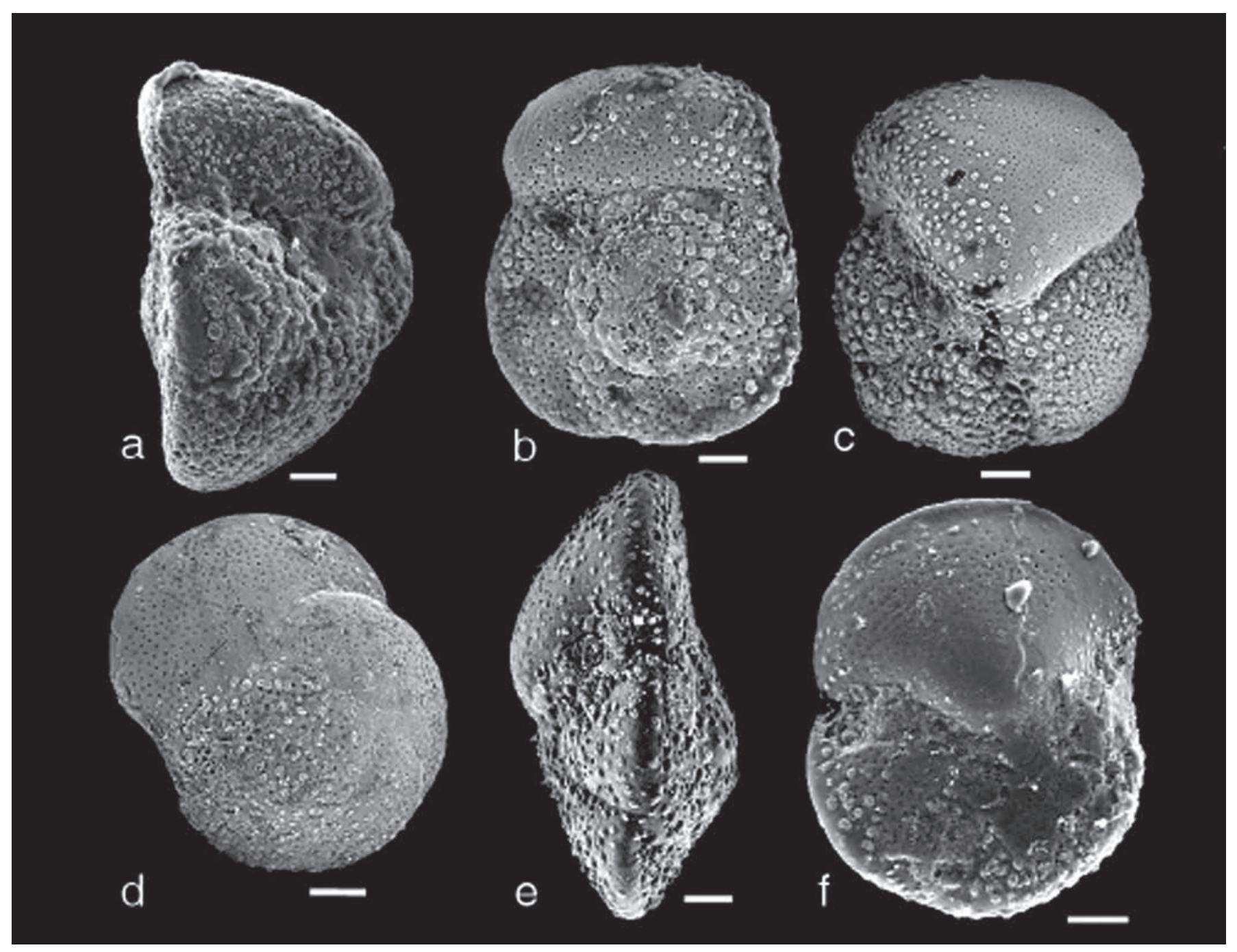

Figure 7. Planktonic foraminifers of biostratigraphic significance found in Velerín Carretera section. a-c, Globorotalia crassaformis Galloway \& Wissler 1927 s.s., lateral (a), spiral (b) and umbilical (c) views (sample Vel-Car-3). d-f, Globorotalia margaritae Bolli \& Bermúdez 1965, spiral (d), lateral (e) and umbilical (f) views (sample Vel-Car-5). 
The nannofossil assemblage present in the Velerín section shows very low abundance and diversity since it corresponds with the most proximal site. It is worth highlighting, however, the presence of Reticulofenestra haqii, R. minutula, R. minuta, Helicosphaera carteri (Wallich) Kamptner 1954 and small Gephyrocapsa.

One sample of the Velerín-Carretera section was analysed (Vel-Car-5). This sample shows similar nannofossil assemblages to those found in the Parque Antena section. That is, small Gephyrocapsa, Reticulofenestra pseudoumbilica and Sphenolithus abies are found.

In Velerín-Antena section, the calcareous nannoplankton of the sample Vel-Ant-4 was studied. The nannofossil assemblage in this sample is characterized by the occurrence of small Gephyrocapsa, Discoaster asymmetricus and D. tamalis, and the absence of Reticulofenestra pseudoumbilica and Sphenolithus abies.

\section{DISCUSSION}

\section{BIOCHRONOLOGY OF THE STUDIED MATE- RIALS}

In all the studied samples, microfossils are abundant, continuously present and generally well preserved. Among foraminifers, no size sorting is observed, a typical feature of reworking. Further, except for a few nannofossil species in some samples, no obvious mixing of species of different ages is recorded. Therefore, microfossil assemblages are mostly composed by temporally coherent species. That is, in most cases there is no biostratigraphic resolution to separate microfossil species of mixed ages due to reworking. This is specially the case for the planktonic foraminifer assemblages, which contain only species of consistent time ranges.

The coexistence of Gr. margaritae, Gr. puncticulata and Gr. group crassaformis among the planktonic fo-

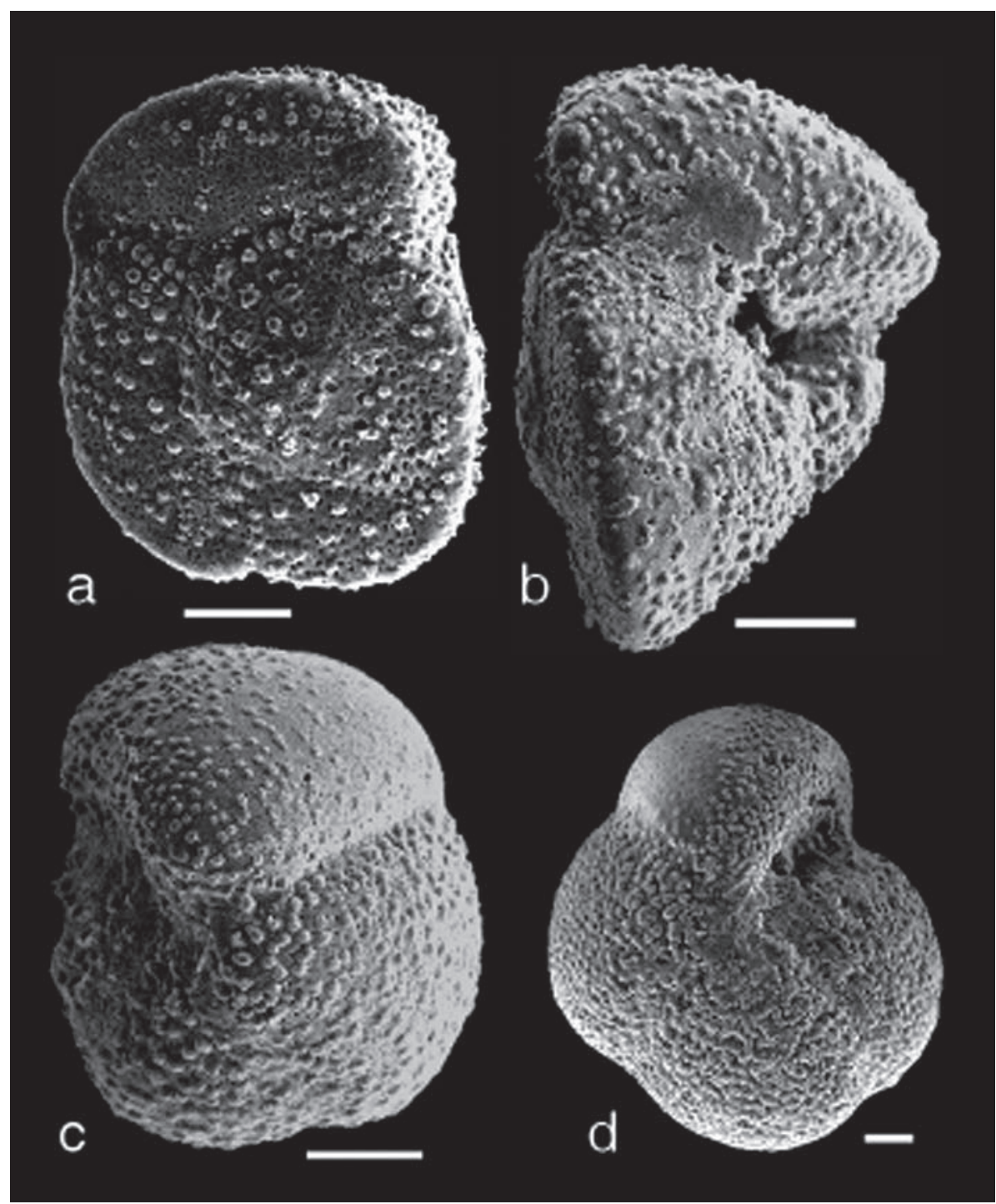

Figure 8. Planktonic foraminifers of biostratigraphic significance found in Velerín Antena section. a-c, Globorotalia crassaformis Galloway \& Wissler 1927 s.s., spiral (a), lateral (b) and umbilical (c) views (sample Vel-Ant-4). d, Globorotalia puncticulata (Deshayes 1832) Banner \& Blow 1970, umbilical view (sample Vel-Ant-4). 
raminifers in Parque Antena section allows us to attribute these materials to the upper part of the Zanclean (early Pliocene). That is, they correspond to the upper part of the PL 2 biozone of Berggren et al. (1995). According to the nannoplankton, the occurrence of small Gephyrocapsa, Sphenolithus abies and Reticulofenestra pseudoumbilica indicates that this site can be included in the CN11b biozone of Okada \& Bukry (1980). This biozone is also upper Zanclean in age (Fig. 10).

In relation to the timing of the sections of the Velerín Area, the low abundance of microfossils due to the shallow depositional conditions at the Velerín section precludes the establishment of any precise age. However, this site could be tentatively attributed to the $\mathrm{CN} 11 \mathrm{~b}$ nannoplankton biozone (early Pliocene) based on the presence of small Gephyrocapsa.

The Velerín-Carretera section, as the Parque Antena section, can also be assigned to the late Zanclean (early Pliocene) according to the planktonic foraminifers (coexistence of Gr. margaritae, Gr. crassaformis s.s., Gr. group crassaformis and Gr. puncticulata) and nannofossils (presence of small Gephyrocapsa, Sphenolithus abies and Reticulofenestra pseudoumbilica) (Fig. 10).

Planktonic foraminifer assemblages at the Velerín-Antena section are characterised by the co-occurrence of $G r$. puncticulata and Gr. crassaformis (Gr. crassaformis s.s and $G r$. group crassaformis) and the absence of Gr. margaritae. With respect to the nannoplankton assemblages, small Gephyrocapsa is present in this site, but Sphenolithus abies and Reticulofenestra pseudoumbilica are absent. Since the last occurrence of Gr. margaritae, Sphenolithus abies and Reticulofenestra pseudoumbilica marks the top of the early Pliocene (Zanclean), this site should be included in the lower part of the middle Pliocene (Piacenzian). The occurrence of Discoaster tamalis and D. asymmetricus allows us to assign this site to the CN12a biozone of Okada \& Bukry, the lowermost biozone of the Piacenzian (Fig. 10).

The age attribution of the studied sites is consistent with the biozonation based on mollusc assemblages (Fig. 11). According to the stratigraphic range of bivalve, gastropod and scaphopod species, the Parque Antena sequence and Velerín area sites can be attributed to the Mediterranean Pliocene Molluscan Unit 1 (MPMU1) of Raffi \& Monegatti (1993) and Monegatti \& Raffi (2001) (Fig. 11). Following these authors, this mollusc unit ranges from the base of the early Pliocene (5.3 Ma) to the lower part of the middle Pliocene, about $3 \mathrm{Ma}$, that is, it is Zanclean-lower Piacenzian in age (Fig. 11).

Additionally, the MPMU1 is defined as characterised by a typical thermophyllic mollusc assemblage (Raffi \& Monegatti, 1993; Monegatti \& Raffi, 2001). The mollusc fauna of the Estepona basin is represented by a great abundance of groups inhabiting present-day warm waters (Vera-Peláez et al., 1995b). Warm water gastropods present in the studied sites are representative of the families Terebridae, Co- nidae, Pleurotomariidae, Ficidae, Amathinidae, Turridae, Mitridae and Olividae, among others. Furthermore, the gastropod Strombus, a typical Senegalese species, is also found in the Velerín Area (Vera-Peláez et al., 1995b).

Among bivalves, it is worth noting the common occurrence of thick-shelled venerids, such as Callista italica Defrance 1818 and Pelecyora gigas Lamarck 1818, as well as Isognomon maxillatus (Lamarck 1801), Tugonia anatinae Gmelin 1791, Lyrocardium and the pectinids Flabellipecten bosniasckii Di Stefani \& Pantanelli 1880 and F. planomedius Sacco 1897 (Lozano-Francisco, 1997). Therefore, both the stratigraphic range and the warm-water affinity of the mollusc species indicate that the studied sediments are attributable to the MPMU1.

In a larger context, and from the perspective of sequence stratigraphy, the Pliocene sediments of southern and southeastern Spain can be divided into two units: a lower unit, the Pliocene I unit, and an upper one, the Pliocene II unit (Montenat, 1977, 1990; Aguirre, 1995a, 1995b, 1998, 2000). Both units are separated by an unconformity that is identified along S-SE Spain and N of Morocco, as well as in the Alborán Sea (see Aguirre, 1995b for a revision). The Pliocene I unit ranges from early Pliocene at the bottom to lowermost middle Pliocene at the top, while the Pliocene II unit is middle-late Pliocene in age (Montenat, 1977, 1990; Aguirre, 1995a, 1995b, 1998, 2000; Aguirre \& Sánchez-Almazo, 1998; Aguirre \& Jiménez, 1998; Aguirre et al., 2002). According to these authors, the boundary between the two units is nearly at $3 \mathrm{Ma}$.

In short, the dating of the studied sites based on microfossils is consistent with the results based on the mollusc assemblages, and with the large scale stratigraphic correlation. That is, the studied deposits range from the upper part of the Zanclean (uppermost early Pliocene) to the lower half of the Piacenzian (middle Pliocene). On the geochronological time scale these deposits can be placed between the first occurrence of Gr. group crassaformis (4.18 Ma, see discussion below), and $\sim 3 \mathrm{Ma}$, the upper limit of the MPMU1 (Figs. 10 and 11).

\section{PALAEOBIOGEOGRAPHIC AND PALAEOCEANO- GRAPHIC IMPLICATIONS}

Up until now, Globorotalia margaritae and Gr. crassaformis have never been found together in the Mediterranean. The appearance of the Gr. crassaformis group in the Mediterranean has been dated at about 3.6 Ma (Hilgen, 1991; Berggren et al., 1995; Lourens et al., 1996; Serrano et al., 1999). On the other hand, the last common occurrence of Gr. margaritae throughout the Mediterranean took place at about 3.8 Ma (Hilgen, 1991; Lourens et al., 1996; Serrano et al., 1999). Therefore, the extinction of Gr. margaritae predates the first appearance of the Gr. crassaformis group by about 200 ky (Fig. 10). In this paper, however, the coexistence of both species has been shown. 

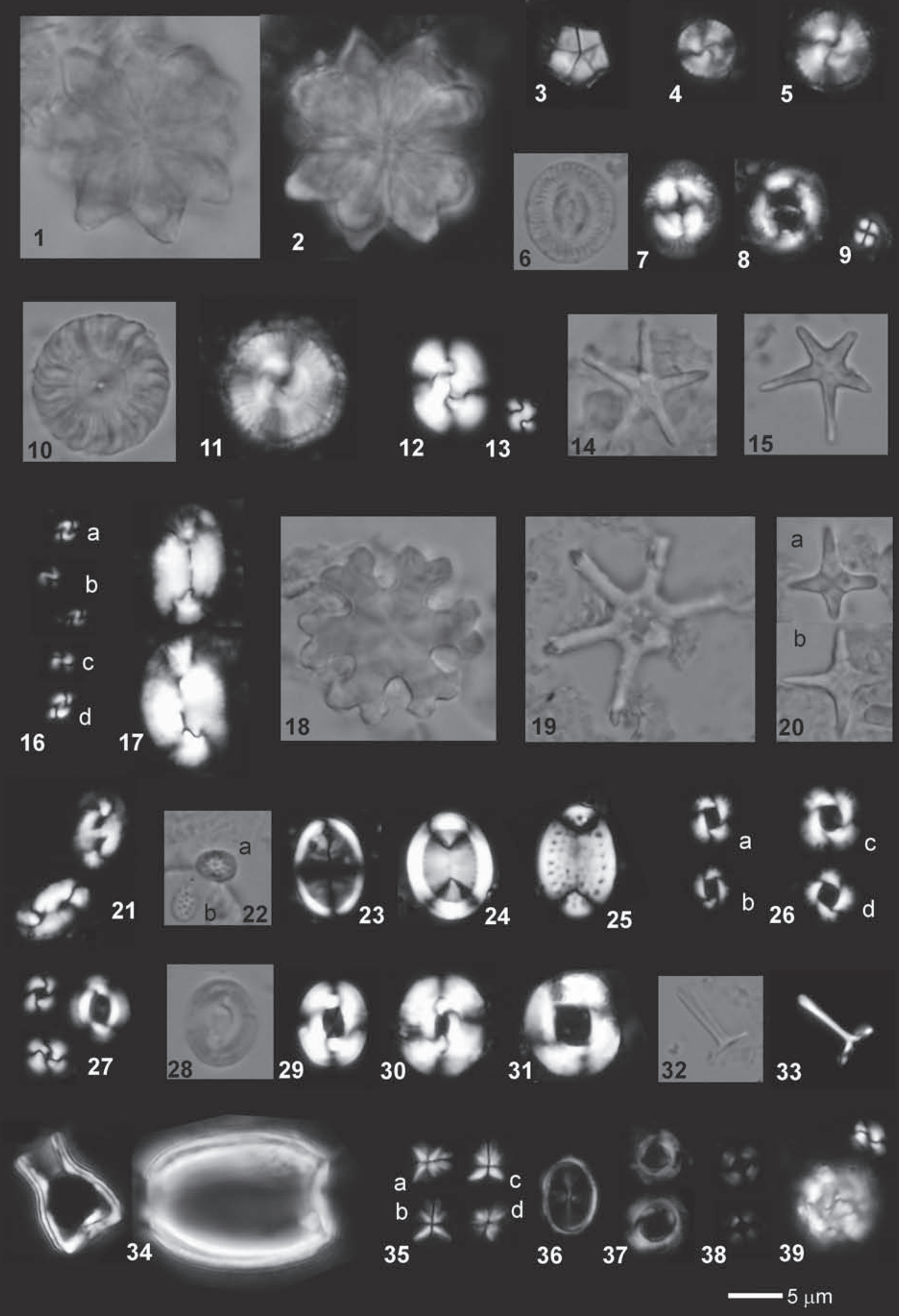
In contrast to the Mediterranean, in the Atlantic Ocean these two species can co-exist. The first occurrence of $G r$. group crassaformis is 4.18 Ma (Berggren et al., 1995), that is, $580 \mathrm{ka}$ earlier than in the Mediterranean. The extinction of $\mathrm{Gr}$. margaritae is dated at $3.58 \mathrm{Ma}$ (Berggren et al., 1995), $220 \mathrm{ky}$ later than in the adjacent Mediterranean. In short, the two species were living together in the Atlantic, at least for $600 \mathrm{ky}$ (Fig. 10).

The coexistence of Gr. margaritae and Gr. group crassaformis in the Estepona basin can be related to temporal invasions of the two species colonizing, at least, the western Mediterranean following the palaeocurrent systems. An antiestuarine palaeocirculation pattern through the Strait of Gibraltar, similar to the one existing at present, was established during the Pliocene (Maldonado, 1989; Hernández-Molina et al., 2002), although some inversions from antiestuarine to estuarine circulation patterns could have taken place during the Quaternary (Maldonado, 1989; but see Cachão \& Moita, 2000). Thus, the Atlantic waters flow into the Mediterranean by superficial currents, while the more saline Mediterranean waters flow out to the Atlantic following deep currents (Fig. 12).

The inflowing superficial Atlantic current forms two anticyclonic gyres in the Alborán Sea (Heburn \& La Violette, 1990), the Western and the Eastern Alborán Gyres, separated by the Alborán Island (Fig. 13). Due to the orientation of the axis of the Strait of Gibraltar in relation to the flow of water entering the Mediterranean, a jet of this superficial current goes northward to the coast of Málaga, while the rest of the water current turns to the south, describing the Western Alborán Anticyclonic Gyre (Hopkins, 1989) (Fig. 13). A complex interaction among different factors (Hopkins, 1989; Heburn \& La Violette, 1990; Robinson \& Golnaraghi, 1994) favours the formation of the Eastern Alborán Gyre, which is further divided into different currents (Fig. 13). One current, the Almería-Omán Front, goes to the east and continues further to the east in the Algerian Current (Arnone et al., 1990) (Fig. 13). The other jet flows to the northeast, to the Levantine Basin, forming a complex pattern of superficial currents (Hopkins, 1989; Robinson \& Golnaraghi, 1994).

According to this circulation pattern, keeled globorotalids, such as Gr. margaritae and Gr. crassaformis could invade the western Mediterranean and reach the Estepona coast, the northwestern margin of the Alborán Sea. The formation of the Eastern Alborán Gyre and the further division of the superficial Atlantic current on the way to the central and eastern Mediterranean could act, at least during certain time intervals, as palaeobiogeographic barriers, inhibiting the displacement of the microorganisms eastwards. This could account for the local extinction of

Figure 9. Calcareous nannoplankton species of the studied sites. 1-2, Ascidean spicule (1, transmitted light; 2, polarized light; Velerín-Carretera site). 3, Braarudosphaera bigelowi (Gran \& Braarud 1935) Deflandre 1947 (pol.; sample Parque Antena5). 4, Calcidiscus leptoporus (Murray \& Blackman 1898) Loeblich \& Tappan 1978 (4, pol., sample Parque Antena-5). 5, Calcidiscus leptoporus (Murray \& Blackman 1898) Loeblich \& Tappan 1978 (pol.; Velerín-Carretera site). 6-7, Coccolithus pelagicus (Wallich 1877) Schiller 1930, larger morphotype (6: transm.; 7: pol.; sample Parque Antena-5). 8, Coccolithus pelagicus (Wallich 1877) Schiller 1930 showing a large open central area with bridge (pol.; sample Parque Antena-6). 9, Coccolithus pelagicus (Wallich 1877) Schiller 1930, small morphotype (pol.; Velerín-Carretera site). 10-11, Calcidiscus macintyrei (Bukry \& Bramlette 1969) Loeblich \& Tappan 1978 (10: transm.; 11: pol.; sample Parque Antena-5). 12, Dictyococcites antarticus Haq 1976 (pol.; sample Parque Antena-5). 13, Dictyococcites productus (Kamptner 1963) Backman 1980 (pol.; sample Parque Antena-6). 14-15, Discoaster asymmetricus Gartner 1969 (transm.; sample Parque Antena-6). 16, Gephyrocapsa spp., small morphotypes (G. aperta Kamptner 1963 and G. ericsonii McIntyre \& Bé 1967) (a and b: sample Parque Antena-5; c: sample Parque Antena-6; and d: Velerín-Carretera site). 17, Helicosphaera carteri (Wallich 1877) Kamptner 1954 (pol.; sample Parque Antena-6). 18, Discoaster deflandrei Bramlette \& Riedel 1954 reworked from Eocene-Miocene (transm.; sample Parque Antena-6). 19, Discoaster surculus Martini \& Bramlette 1963 (transm.; Velerín-Carretera site). 20, Discoaster tamalis (transm.; a: samples Parque Antena-6; and b: Velerín-Carretera site). 21, Helicosphaera sellii Bukry \& Bramlette 1969 (pol.; sample Parque Antena-5). 22, Holodiscolithus macroporus (Deflandre in Deflandre \& Fert 1954) Roth 1970 (transm.; a: samples Parque Antena-5; and b: Velerín-Carretera site). 23, Pontosphaera discopora Schiller 1925 (pol.; sample Parque Antena-6). 24, Pontosphaera discopora (pol.; sample Velerín-Carretera site). 25, Pontosphaera multipora (Kamptner 1948) Roth 1970 (pol.; sample Parque Antena-6). 26, Pseudoemiliania ovata (Bukry 1973) Young 1998 (pol.; a: sample Parque Antena-5; and b: Parque Antena-6). 26, Pseudoemiliania lacunosa (Kamptner 1963) Gartner 1969 (pol.; c and d: sample Velerín-Carretera site). 27, Small morphotypes: Reticulofenestra minuta Roth 1970; larger morphotype: Reticulofenestra gr. haqii-minutula [R. haqii Backman 1978; R. minutula (Gartner 1967) Haq \& Berggren 1978] (pol.; sample Parque Antena-6). 28-29, Reticulofenestra pseudoumbilica (Gartner 1967) Gartner 1969 (28: transm.; 29: pol.; sample Parque Antena-5). 30-31, closed and open central area morphotypes, respectively, of Reticulofenestra psudoumbilicus (pol.; sample Parque Antena-6). 32-33, Rhabdosphaera gr. stilifera-clavigera [R. stilifera (Lohmann 1902) Kleijne \& Jordan 1990; R. clavigera Murray \& Blackman,1898 (32: transm.; 33: pol.; sample Parque Antena-5). 34, two morphotypes of Scyphosphaera spp. (pol.; Velerín-Carretera site). 35, Sphenolithus abies Deflandre in Deflandre \& Fert 1954 (pol.; sample Parque Antena-6). 36, Syracosphaera gr. histrica-pulchra [S. hirsuta Kamptner 1941; S. pulchra Lohmann 1902] (pol.; sample Velerín-Carretera site). 37, Umbilicosphaera rotula (Kamptner 1956) Varol 1982 (pol.; sample Parque Antena-6). 38, Umbilicosphaera jafari Muller, 1974 (pol.; sample Parque Antena-6). 39, Coccosphere and isolated coccolith of $R$. minuta (pol.; Velerín-Carretera). 
Gr. margaritae in the Mediterranean except in the western Alborán Sea. Further studies are needed to discern why Gr. margaritae underwent this limited displacement into the Mediterranean at the late early Pliocene (during the uppermost part of its temporal range) compared with the earlier, wider distribution throughout the Mediterranean. Additionally, the delayed expansion of Gr. crassaformis throughout the Mediterranean with respect to its appearance in the Atlantic Ocean, during the lower part of the Piacenzian (middle Pliocene) has to be also investigated.

The influence of Atlantic superficial waters in the west- ern Mediterranean is also confirmed by the occurrence of some genera and families of molluscs with Atlantic affinities: 1) Dentalium and Fissidentalium among scaphopods; 2) Isognomon, Flabellipecten, Lyrocardium, Plicatulidae and Myidae among bivalves; and, 3) Pleurotomariidae, Ficidae, Amathinidae, Terebridae, Olividae, Conidae, as well as some genera within the Turridae, Volutidae and archaeogastropods among gastropods. Silva $(2001,2002)$ has reported the presence of some genera of gastropods from the Mondego basin (Portugal), such as Ansates, Persicula, Scaphella and Amalda (among others), in the Estepona basin.

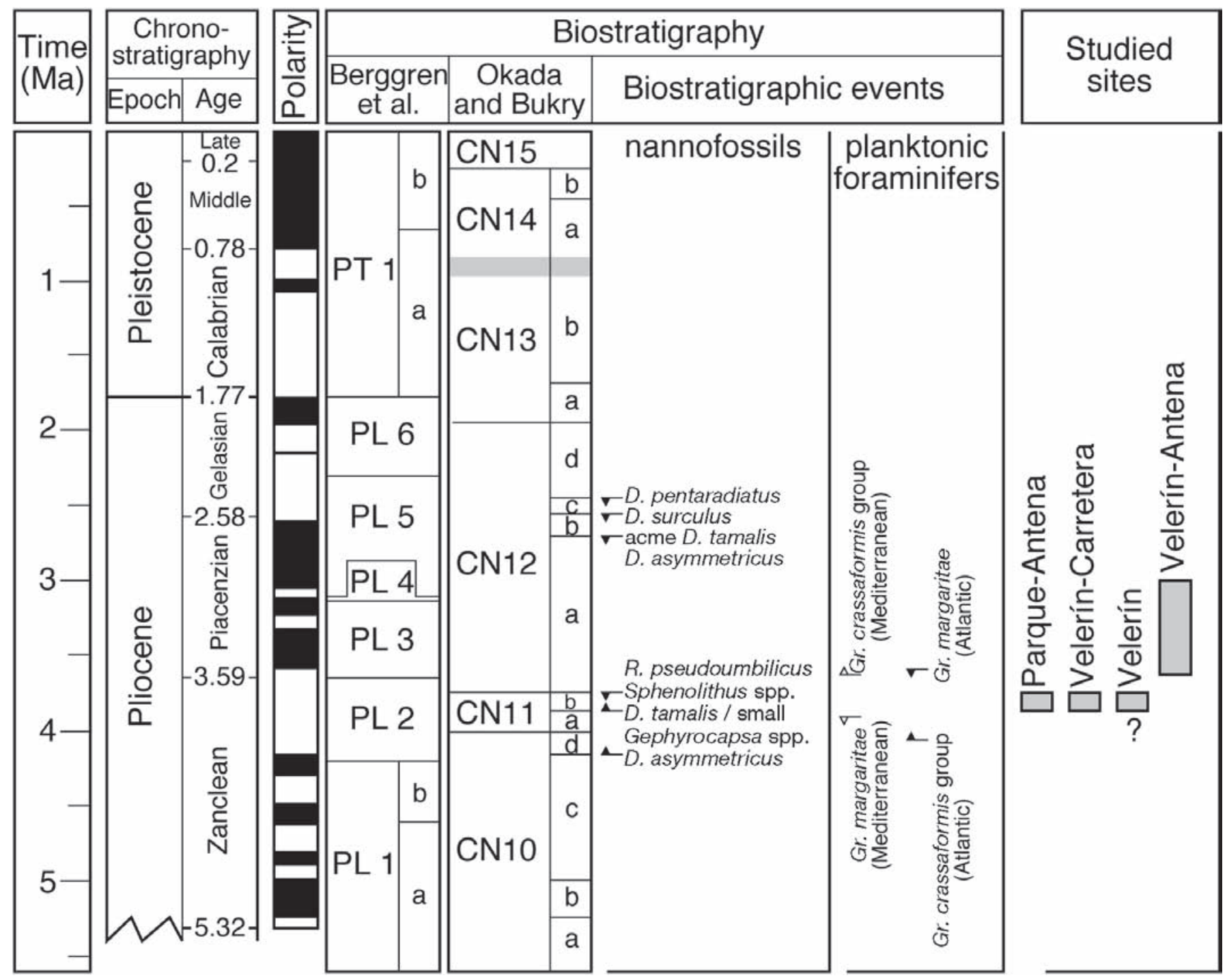

Figure 10. Biostratigraphic events of calcareous microfossils (nannofossils and planktonic foraminifers), biostratigraphic biozonation of planktonic foraminifers from Berggren et al. (1995), biostratigraphic biozonation of calcareous nannoplankton from Okada \& Bukry (1980), and the stratigraphic ranges of the studied sites. Chronostratigraphy and magnetic polarity chrons are from Berggren et al. (1995). The virtual absence of microfossils in the Velerín site precludes any biostratigraphic positioning of this site. However, the presence of small Gephyrocapsa allows us to attribute this site tentatively (?) to the CN11b biozone. Regarding the planktonic foraminifers, the first appearance of the Globorotalia crassaformis group and the last occurrence of Globorotalia margaritae is indicated both in the Mediterranean (white arrows) and in the Atlantic (black arrows). These datum events clearly show that both species did not coexist in the Mediterranean, while they did in the Atlantic, however, we have found them coexisting in the studied sites. 
Within this palaeoceanographic scenario, local upwelling currents could develop along part of the coast of Málaga, which would account for the high percentage of Ceratolithus pelagicus (Wallich 1877) Schiller 1930, a nannoplankton species that typically occurs in sea waters with high nutrient content (Cachão, 1995; Cachão \& Moita, 2000). High nutrients and food supply due to upwellings would also account for the high diversity of fauna in the Estepona basin, as well as other Pliocene basins distributed along the Málaga coast (Fig. 3), during the early-lowermost middle Pliocene.

\section{CONCLUSIONS}

In the Estepona basin (Málaga, S Spain), the richest and most diverse Pliocene macrofossil assemblages of the Mediterranean domain have been reported. Up until now, nearly 1,300 species of marine invertebrates have been inventoried, most of them being molluscs (892 species). 95\% of the total identified molluscs are only found in two sites, the Parque Antena site and the Velerín Area (Velerín, Velerín-Carretera and Velerín-Antena sites). Notwithstanding the great knowledge of the macrofauna, the age of these sites still remains controversial. The integrated study of the microfossil assemblages (planktonic foraminifers and calcareous nannoplankton), together with the molluscs, allows us to precisely establish the age of these deposits.

Both the Parque Antena and Velerín-Carretera sites are late Zanclean (uppermost early Pliocene) in age. This age attribution is based on the co-occurrence of Globorotalia margaritae, Gr. puncticulata and Gr. crassaformis (Gr. crassaformis s.s. and Gr. group crassaformis) among the planktonic foraminifers, and small Gephyrocapsa $(<3 \mu \mathrm{m})$, Sphenolithus abies and Reticulofenestra pseudoumbilica among the calcareous nannoplankton. The planktonic foraminifers characterise the PL 2 biozone of Berggren et al. (1995) and the nannofossils restrict the deposits to the CN11b biozone of Okada \& Bukry (1980).

In the Velerín-Antena section, the lower Pliocene bio-

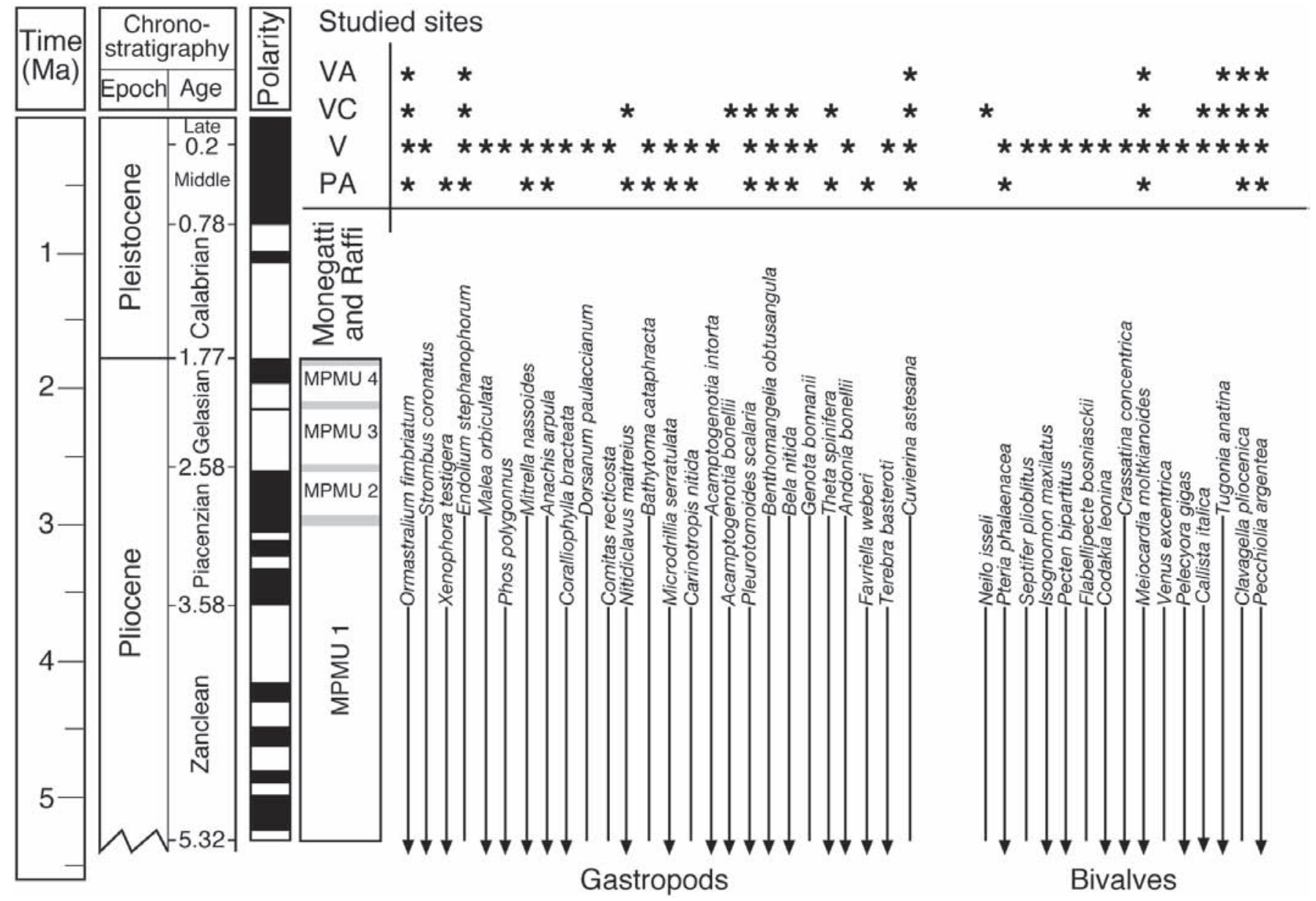

Figure 11. Mediterranean Pliocene Mollusc Units (MPMU) of Monegati \& Raffi (2001) and the stratigraphic ranges of gastropod and bivalve species found in the studied sites: PA, Parque Antena; V, Velerín; VC, Velerín-Carretera; VA, Velerín-Antena. Arrows indicate that the stratigraphic ranges of these species extend to older times. The stratigraphic ranges of these mollusc species allow us to constraint the age of the studied sites to the top of the MPMU1. 
markers Gr. margaritae, Sphenolithus abies and Reticulofenestra pseudoumbilica are absent. Here, the microfossil assemblages are characterised by the occurrence of Gr. puncticulata, Gr. crassaformis among the planktonic foraminifers, and Discoaster tamalis and D. asymmetricus among the nannofossils. This microfossil assemblage allows us to assign the Velerín-Antena section to the CN12a biozone of Okada \& Bukry (1980); that is, lower part of the middle Pliocene (Piacenzian).

The age attribution of the studied fossiliferous sites can be further constrained based on the mollusc assemblages. The rich and diversified mollusc assemblages found in the Parque Antena and Velerín Area sites can be correlated with the Mediterranean Pliocene Molluscan Unit 1 (MPMU1) of Raffi \& Monegatti (1993). This unit ranges from the base of the Zanclean (5.3 Ma) to the lower half of the Piacenzian, the top of the unit being established at 3 Ma (Monegatti \& Raffi, 2001).

On the other hand, this study shows the co-occurrence of Gr. margaritae and Gr. crassaformis in the Mediterranean domain for the first time. According to the published data, the last common occurrence of Gr. margaritae (3.8 Ma) predates by about $200 \mathrm{ky}$ the first occurrence of $G r$. crassformis in the Mediterranean (3.6 Ma). Nevertheless, in the Atlantic Ocean, these two species coexisted for $600 \mathrm{ky}$, from $4.18 \mathrm{Ma}$ (first occurrence of Gr. group crassaformis) to $3.58 \mathrm{Ma}$ (the extinction of Gr. margaritae). Therefore, faunal interchanges through the Strait of Gibraltar due to palaeocurrent circulation patterns could account for the coexistence of both planktonic foraminifer species in the Estepona basin. The superficial Atlantic waters enter the Mediterranean, producing the Western and Eastern Alborán Anticyclonic Gyres, both separated by the Alborán Island. The complex interaction of different factors that caused this circulation pattern in the Alborán Sea could act as a biogeographic barrier that precluded the expansion of Gr. margaritae further to the east in the Mediterranean during the uppermost part of the early Pliocene. The occurrence of Atlantic gastropods of some Pliocene Portuguese basins (Ansates, Persicula, Scaphella and Amalda) in some basins of the province of Málaga is consistent with this interpretation.
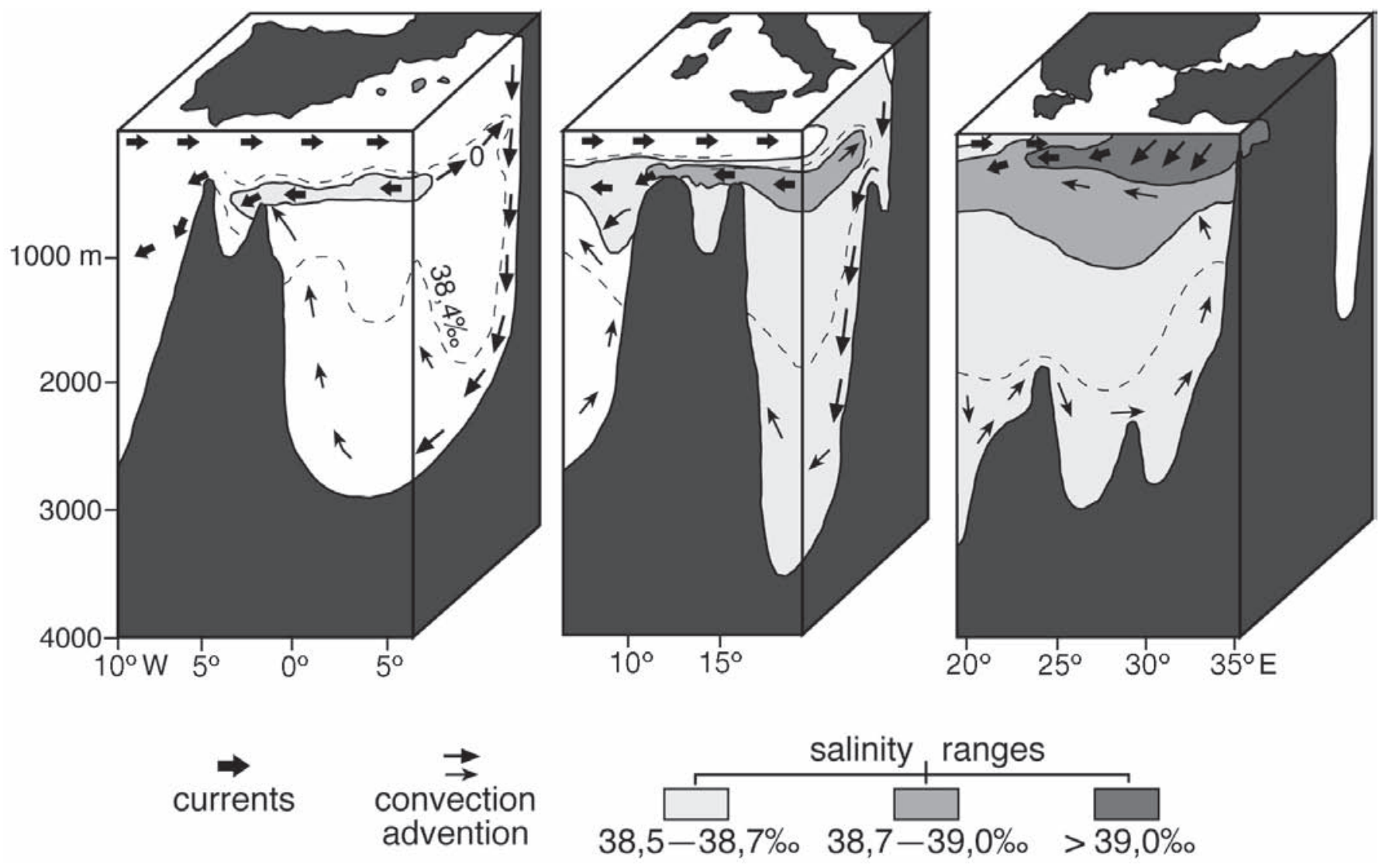

Figure 12. Circulation pattern of water masses through the Strait of Gibraltar and in the Mediterranean (Modified from Wüst, 1961). The Atlantic waters flow into the Mediterranean by superficial currents, while the denser and more saline waters of the Mediterranean travel to the Atlantic following deep currents. 


\section{TAXONOMIC APPENDIX}

Zachariasse (1975) established the Globorotalia crassaformis group to merge several species of planktonic foraminifers that currently occur in Pliocene deposits of the Mediterranean. This group includes six species: Gr. crassaformis Galloway \& Wissler 1927, Gr. crassula Cushman \& Stewart 1930, Gr. crassacrotonensis Conato \& Follador 1967, Gr. crotonensis Conato \& Follador 1967, Gr. hirsuta aemiliana Colalongo \& Sartoni 1967 and Gr. planoconvexa Hug 1970. These species are mainly distinguished based on the convexity of the umbilical side, the equatorial outline and the character of the periphery (Zachariasse, 1975: 111). We have adopted this taxonomic grouping.

In the Pliocene deposits of Crete, Zachariasse (1975) differentiated two morphotypes within this group. One group includes Gr. crassaformis and Gr. crassula and fits very well with the type of Gr. crassaformis. The other comprises Gr. crassacrotonensis, Gr. crotonensis, Gr. hirsuta aemiliana and Gr. planoconvexa and fits with the type material of Gr. crassacrotonensis. The former morphotype is found in lower-middle Pliocene deposits, while the latter occurs in upper Pliocene sediments.

In the material studied in the Estepona basin, the specimens found in the lower Pliocene deposits of Parque Antena site show globose chambers and subacute periphery, and the test is markedly planoconvex (Figs. 6b-c). These morphological features allow us to attribute this morphotype to Gr. crassaformis as described by Zachariasse (1975). On the other hand, the specimens from the Velerín-Carretera (Figs. 7a-c) and Velerín-Antena (Figs. $8 \mathrm{a}-\mathrm{c})$ sections have a quadrangular outline; show a very distinctive acute periphery, with nearly keeled chambers; and posses a lower umbilical side. This morphology approaches to the type of Gr. crassacrotonensis according to the distinction made by Zachariasse (1975).

\section{ACKNOWLEDGEMENTS}

The authors want to acknowledge the reviewers Drs. José Angel González-Delgado and José María González-Donoso (in collaboration with Antonio Guerra-Merchán and Francisco Serrano). Their suggestions and comments have improved the paper. We also thank the editorial advises by Dr. Rodolfo Gozalo. SEM photographs were carried out in the CEAMA (Centro Andaluz de Medio Ambiente) in Granada by Dr. Isabel M $M^{\text {a }}$ Sánchez-Almazo. Antonio García Alix helped us with the final edition of the pictures of the foraminifers. This paper has been supported by the Research Project "Paleobiología de las cuencas marinas de Estepona, Málaga y Vélez-Málaga”, funded by the Junta de Andalucía. The English text has been corrected by Jodi Eckart.

\section{REFERENCES}

Aguirre, J. 1995a. Tafonomía y evolución sedimentaria del Plioceno marino en el litoral sur de España entre Cádiz. y Almería. Tesis Doctoral, Universidad de Granada, 419 pp. (inédita).

Aguirre, J. 1995b. Implicaciones paleoambientales y paleogeográficas de dos discontinuidades estratigráficas en los

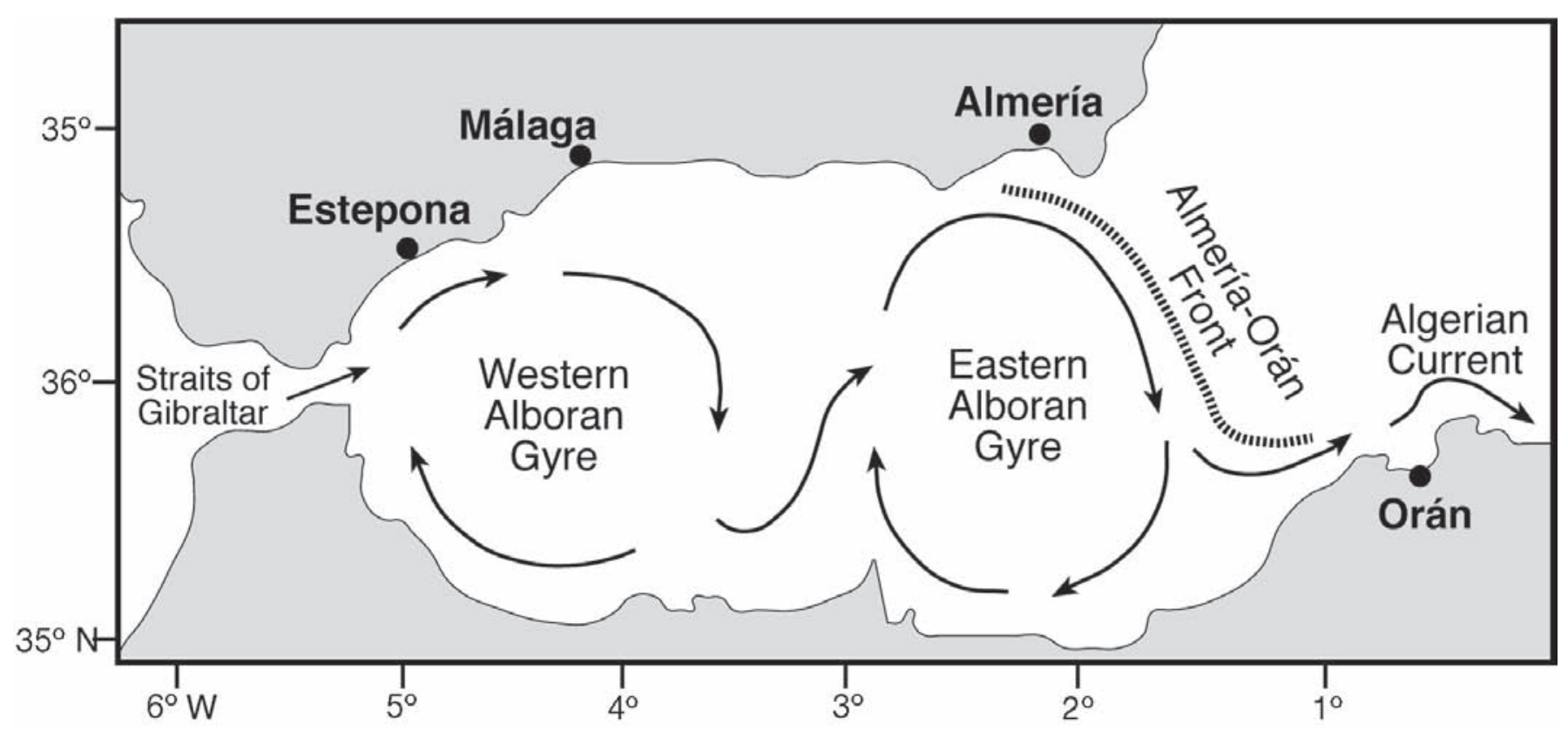

Figure 13. Superficial Atlantic waters in the Alborán Sea (modified from Arnone et al., 1990). The inflowing Atlantic waters form two anticyclonic gyres, the Western and the Eastern Alboran Gyres. The superficial current of the Eastern Gyre is divided again, forming the Almería-Orán Front which continues further east in the Algerian Current. Globorotalia margaritae could invade the Alborán Sea following the superficial Atlantic waters. The complex circulation pattern of the Atlantic water jet, on its way to the centre and east Mediterranean could act as a palaeobiogeographic barrier, limiting the displacement of this species eastward. 
depósitos pliocénicos de Cádiz (SW de España). Revista de la Sociedad Geológica de España, 8, 153-166.

Aguirre, J. 1998. El Plioceno del SE de la península Ibérica (provincia de Almería). Síntesis estratigráfica, sedimentaria, bioestratigráfica y paleogeográfica. Revista de la Sociedad Geológica de España, 11, 297-315.

Aguirre, J. 2000. Evolución paleoambiental y análisis secuencial de los depósitos pliocenos de Almayate (Málaga, sur de España). Revista de la Sociedad Geológica de España, 13, 431-443.

Aguirre, J. \& Jiménez, A.P. 1998. Fossil analogues of the present-day ahermatypic Cladocora caespitosa coral banks: Sedimentary setting, dwelling community, and taphonomy (late Pliocene, W Mediterranean). Coral Reefs, 17, 203-213.

Aguirre, J. \& Sánchez-Almazo, I.M. 1998. Foraminiferal assemblages in Upper Pliocene deposits of Almería-Níjar Basin (SE Spain): Biostratigraphic and palaeoenvironmental significance. 15th International Sedimentological Congress, Universidad de Alicante, 120.

Aguirre, J., Márquez-Crespo, R., Pérez-Muñoz, A.B., Sánchez-Almazo, I.M. \& Yesares-García, J. 2002, Síntesis paleontológica del Plioceno inferior de la cuenca de Almería-Níjar (SE de España). Pliocénica, 2, 8-30.

Ansted, D.T. 1857. On the geology of Malaga and the southern part of Andalucía. Quarterly Journal, 15, 585-604.

Arnone, R.A., Wiesenburg, D.A. \& Saunders, K.D. 1990. The origin and characteristics of the Algerian Current. Journal of Geophysical Research, 95 (C2), 1587-1598.

Berggren, W.A., Kent, D.V., Swicher, C.C., III \& Aubry, M.P. 1995. A revised Cenozoic geochronology and chronostratigraphy. In: Geochronology, time scales and global stratigraphic correlation (Eds. W.A. Berggren, D.V. Kent, M.P. Aubry \& J. Hardenbol). SEPM (Society for Sedimentary Geology), Tulsa. Special Publication No. 54, 129-212.

Bertrand, M. \& Kilian, M. 1892. Estudio de los terrenos Secundarios y Terciarios de las provincias de Granada y Málaga. Boletín de la Comisión del Mapa Geológico de España, 18, 257-447.

Cachão, M. 1995. Utilização de nanofósseis calcários em biostratigrafia, paleoceanografia e paleoecologia. Aplicações ao neogénico do Algarve (Portugal) e do Mediterrâneo ocidental (ODP 653) e à problemática do Coccolithus pelagicus. Tesis Doctoral, Faculdade de Ciencias da Universidade de Lisboa, 356 pp. (inédita).

Cachão, M. \& Moita, M.T. 2000. Coccolithus pelagicus, a productivity proxy related to moderate fronts off western Iberia. Marine Micropaleontology, 39,131-155.

Chamon, C., Estévez, C. \& Piles, E. 1978. Mapa Geológico de España, 1:50.000, MAGNA, hoja no 1072 (Estepona). Servicio de Publicaciones del Ministerio de Industria y Energía, Madrid, 34 pp.

Cita, M.B. 1975. Studi sul Pliocene e sugli strati di passaggio dal Miocene al Pliocene. VIII. Planktonic foraminiferal biozonation of the Mediterranean Pliocene deep sea record. A revision. Rivista Italiana di Paleontologia, 81, 527-544.
Dowsett, H.J. \& Poore, R.Z. 1990. A new planktic foraminifer transfer function for estimating Pliocene-Holocene paleoceanographic conditions in the North Atlantic. Marine Micropaleontology, 16, 1-23.

González-Donoso, J.M. \& de Porta, J. 1977. Datos preliminares sobre un afloramiento de materiales pliocénicos en Estepona (provincia de Málaga). Studia Geológica, 13, 313-57.

Guerra-Merchán, A. \& Serrano, F. 1993. Análisis estratigráfico de los materiales Neógeno-Cuaternarios de la región de Nerja. In: Geología de la Cueva de Nerja. Patronato de la Cueva de Nerja (Ed. F. Carrasco). Trabajos sobre la Cueva de Nerja, 3, 55-90.

Guerra-Merchán, A., Serrano, F. \& Ramallo, D. 2002. Evolución sedimentaria y paleogeográfica pliocena del borde septentrional de la cuenca de Estepona (provincia de Málaga, Cordillera Bética). Pliocénica, 2, 31-43.

Heburn, G.W. \& La Violette, P.E. 1990. Variations in the structure of the anticyclonic gyres found in the Alboran Sea. Journal of Geophysical Research, 95 (C2), 15991613.

Hernández-Molina, F.J., Somoza, L., Vázquez, J.T., Lobo, F., Fernández-Puga, M.C., Llave, E. \& Díaz-del Río, V. 2002. Quaternary stratigraphic stacking patterns on the continental shelves of the southern Iberian Peninsula: Their relationship with global climate and palaeoceanographic changes. Quaternary International, 92, 5-23.

Hilgen, F.J. 1991. Extension of the astronomically calibrated (polarity) time scale to the Miocene/Pliocene boundary. Earth and Planetary Science Letters, 107, 349-368.

Hopkins, T.S., 1989. La física del mar. In: El Mediterráneo Occidental (Ed. R. Margalef). Omega, Barcelona, 102127.

Iaccarino, S. 1985. Mediterranean Miocene and Pliocene planktic foraminifera. In: Plankton stratigraphy (Eds. H.M. Bolli, J.B. Saunders \& K. Perch-Nielsen). Cambridge Earth Science Series. Cambridge University Press, Cambridge, 283-314.

Keigwin, L.D. 1986. Pliocene stable-isotope record of Deep Sea Drilling Project Site 606: Sequential events of ${ }^{18} \mathrm{O}$ enrichment beginning at 3.1 Ma. In: Initial Reports of the Deep Sea Drilling Project (Eds. W.F. Ruddiman, R.B. Kidd, E. Thomas, et al.), 94, 911-920.

Lévy, M. \& Bergeron, M.M. 1892. Estudio geológico de la Serranía de Ronda. Boletín de la Comisión del Mapa Geológico de España, 17, 179-352.

Lourens, L.J., Antonarakou, A., Hilgen, F.J., Van Of., A.A.M., Vergnaud-Grazzini, C. \& Zachariasse, W.J. 1996. Evaluation of the Plio-Pleistocene astronomical timescale. Paleoceanography, 11, 391-413.

Lozano-Francisco, M.C. 1997. Los bivalvos del Plioceno de la provincia de Málaga. Tesis Doctoral, Universidad de Málaga, 734 pp. (inédita).

Lozano-Francisco, M.C. 1998. Los bivalvos (Mollusca, Bivalvia) del Plioceno de la provincia de Málaga (España). Malakos, 6-7, 16-58.

Lozano-Francisco, M.C. \& Vera-Peláez, J.L. 2002. Estudio preliminar del Orden Archaeogastropoda (Gastropoda, 
Prosobranchia) del Plioceno de la cuenca de Estepona (Málaga, S España) con la descripción de doce nuevas especies. Pliocénica, 2, 157-175.

Lozano-Francisco, M.C., Vera-Peláez, J.L. \& Guerra-Merchán, A. 1993. Arcoida (Mollusca, Bivalvia) del Plioceno de la provincia de Málaga, España. Treballs del Museo de Geologia de Barcelona, 3, 157-188.

Lyell, C. 1833. Principles of geology. Volume III (1st Edition). Facsimil edition published by the University of Chicago Press, 398 pp.

Maldonado, A. 1989. Evolución de las cuencas mediterráneas y reconstrucción detallada de la paleoceanografía cenozoica. In: El Mediterráneo occidental (Ed. R. Margaleff). Omega, Barcelona, 18-61.

Maslin, M.A., Li, X.S., Loutre, M.F. \& Berger, A. 1998. The contributions of orbital forcing to the progressive intensification of Northern Hemisphere glaciation. Quaternary Science Review, 17, 411-426.

Mayoral, E. \& Rodríguez-Vidal, J. 1994. Aspectos morfosedimentarios de la transgresión pliocena en Almayate (Málaga). Geogaceta, 16, 110-113.

Monegatti, P. \& Raffi, S. 2001. Taxonomic diversity and stratigraphic distribution of Mediterranean Pliocene bivalves. Palaeogeography, Palaeoclimatology, Palaeoecology, 165, 171-193.

Montenat, C. 1977. Les Bassins Néogènes du Levant d'Alicante et de Murcia (Cordillères Bétiques Orientales - Espagne). Stratigraphie, Paleogeographie et Evolution Dynamique. Documents del Laboratoire de Geologie dela Faculte de Sciences de Lyon, 69, 1-345.

Montenat, C. (Ed.). 1990. Les bassins Néogènes du domaine Bétique oriental (Espagne). Documents et Travailles IGAL, 12-13, 392 pp.

Muñiz-Solís, R. 2002. Estudio de las familias Cystidae Stimpson, 1865 y Marginellidae Fleming, 1828 (Gastropoda, Neogastropoda) del Plioceno de Estepona (Málaga, España). Pliocénica, 2, 263-306.

Muñiz-Solís, R., Vera-Peláez, J.L., Martinell, J., Doménech, R., Lozano-Francisco, M.C. \& Guerra-Merchán, A. 1996. Cassidae (Gastropoda) del Plioceno de Málaga. Coloquios de Paleontología, 48, 103-124.

Okada, H. \& Bukry, D. 1980. Supplementary modification and introduction of code numbers to the low-latitude coccolith biostratigraphic zonation. Marine Micropaleontology, 5, 321-325.

Raffi, S. \& Monegatti, P. 1993. Bivalve taxonomic diversity throughout the Italian Pliocene as a tool for climaticoceanographic and stratigraphic inferences. Ciências $d a$ Terra, 12, 45-50.

Raffi, S., Stanley, S.M. \& Marasti, R. 1985. Biogeographic patterns and Plio-Pleistocene extinction of Bivalvia in the Mediterranean and southern North Sea. Paleobiology, 11, 368-388.

Raffi, S., Monegatti, P. \& Marasti, R. 1989. East Atlantic molluscan province boundaries and Mediterranean Neogene extinctions. Atti $3^{\circ}$ Simposio di Ecologia e Paleoecologia delle Comunità Bentoniche. Universidad de Catania, Sicilia, 321-332.
Robinson, A.R. \& Golnaraghi, M. 1994. The physical and dynamical oceanography of the Mediterranean Sea. In: Ocean processes in climate dynamics: Global and Mediterranean examples (Eds. P. Malanotte-Rizzoli \& A.R. Robinson). Kluwer Academic Press, in cooperation with NATO Scientific Affairs Division, 255-306.

Ruddiman, W.F. \& Raymo, M.E. 1988. Northern hemispheric climate regimens during the past $3 \mathrm{Ma}$ : Possible tectonic conditions. Philosophical Transactions of the Royal Society of London, B318, 411-430.

Serrano, F., González-Donoso, J.M. \& Linares, D., 1999. Biostratigraphy and paleoceanography of the Pliocene at Sites 975 (Menoría Rise) and 976 (Alboran Sea) from a quantitative analysis of the planktonic foraminiferal assemblages. In: Proceedings of the Ocean Drilling Program, Scientific Results (Eds. R. Zahn, M.C. Comas \& A. Klaus), 161, 185-195.

Shackleton, N.J., Backman, J., Zimmerman, H., Kent, D.V., Hall, M.A., Roberts, D.G., Schnitker, D., Baldauf, J.G., Desprairies, A., Homrighausen, R., Huddlestun, P., Keene, J.B., Kaltenback, A.J., Krumsiek, K.A.O., Morton, A.C., Murray, J.V. \& Westberg-Smith, J. 1984. Oxygen isotope calibration of the onset of ice-rafting and history of glaciation in the north Atlantic region. Nature, 307, 620-623.

Silva, C.M. da 2001. Gasterópodes Pliocénicos marinhos de Portugal. Sistemática, paleoecologia, paleobiologia, paleobiogeografia. Ph.D. Thesis, Universidade de Lisboa, 747 pp. (inédita).

Silva, C.M. da 2002. Novos dados sobre os moluscos Pliocénicos marinhos de Portugal: Implicações paleoceanográficas e paleobiogeográficas. Pliocénica, 2, 117-125.

Thiede, J., Winkler, A., Wolf-Welling, T., Eldholm, O., Myhre, A.M., Baumann, K.H., Henrich, R. \& Stein, R. 1998. Late Cenozoic history of the polar North Atlantic: Results from ocean drilling. Quaternary Science Review, 17, 185-208.

Vera-Peláez, J.L. 1996. Turridae (Mollusca, Gastropoda) del Plioceno malacitano. Tesis Doctoral, Universidad de Málaga, 864 pp. (inédita).

Vera-Peláez, J.L. 2002. Revisión de la familia Turridae, excepto Clavatulinae (Gastropoda, Prosobranchia) en el Plioceno de las cuencas de Estepona, Málaga y VélezMálaga (Málaga, S España) con la descripción de 26 especies. Pliocénica, 2, 176-262.

Vera-Peláez, J.L. \& Aguilà, J.B. 1996. La subfamilia Crassipirinae MORRISON, 1966 (Turridae, Gastropoda) del Neógeno de la Península Ibérica. Malakos, 5, 35-52.

Vera-Peláez, J.L. \& Lozano-Francisco, M.C. 1998a. La subfamilia Clathurellinae (Gastropoda, Turridae) en el Plioceno de Estepona (Málaga, España). Malakos, 6-7, 96-131.

Vera-Peláez, J.L. \& Lozano-Francisco, M.C. 1998b. La subfamilia Conorbiinae De Gregorio, 1890 (Turridae, Gastropoda) en el Plioceno inferior de Málaga (España). Malakos, 6-7, 133-157.

Vera-Peláez, J.L. \& Lozano-Francisco, M.C. 2002. Perotrochus brachoi, nueva especie de la familia Pleurotomariidae Swainson, 1840 (Gastropoda, Prosobranchia) del Plioceno de Estepona (Málaga, sur de España). Pliocénica, 2, 151-156. 
Vera-Peláez, J.L., Lozano-Francisco, M.C. \& Guerra-Merchán, A. 1993. Escafópodos (Mollusca, Scaphopoda) del Plioceno de la provincia de Málaga, España. Treballs del Museo de Geologia de Barcelona, 3, 117-156.

Vera-Peláez, J.L., Muñiz-Solís, R., Lozano-Francisco, M.C., Martinell, J., Doménech, R. \& Guerra-Merchán, A. 1995a. Cancellariidae Gray, 1853 del Plioceno de la provincia de Málaga, España. Treballs del Museo de Geologia de Barcelona, 4, 133-179.

Vera-Peláez, J.L., Lozano-Francisco, M.C., Muñiz-Solís, R., Gili, C., Martinell, J., Doménech, R., Palmqvist, P. \& Guerra-Merchán, A. 1995b. Estudio preliminar de la malacofauna del Plioceno de Estepona (Málaga, España). Iberus, 13, 93-117.
Vera-Peláez, J.L., Martinell, J. \& Lozano-Francisco, M.C. 1999. Turridae (Gastropoda, Prosobranchia) del Plioceno inferior de Málaga (España). Iberus, 17, 1-19.

Wüst, G. 1961. On the vertical circulation of the Mediterranean Sea. Journal of Geophysical Research, 66, 3261-3271.

Zachariasse, W.J. 1975. Planktonic foraminiferal biostratigraphy of the Late Neogene of Crete (Greece). Utrecht Micropaleontological Bulletin, 11, 1-171.

Manuscrito recibido: 15 de Octubre, 2004 Manuscrito aceptado: 14 de Octubre, 2005 